\title{
Dimethylsulfide (DMS), marine biogenic aerosols and the ecophysiology of coral reefs
}

\author{
Rebecca L. Jackson ${ }^{1,2}$, Albert J. Gabric ${ }^{2,3}$, Roger Cropp ${ }^{1}$, and Matthew T. Woodhouse ${ }^{4}$ \\ ${ }^{1}$ School of Environment and Science, Griffith University, Gold Coast, QLD, Australia \\ ${ }^{2}$ Australian Rivers Institute, Griffith University, Gold Coast, QLD, Australia \\ ${ }^{3}$ School of Environment and Science, Griffith University, Nathan, QLD, Australia \\ ${ }^{4}$ Climate Science Centre, Oceans and Atmosphere, Commonwealth Scientific and Industrial Research Organisation, \\ Aspendale, VIC, Australia
}

Correspondence: Rebecca L. Jackson (rebecca.jackson7@griffithuni.edu.au)

Received: 27 May 2019 - Discussion started: 30 September 2019

Revised: 10 March 2020 - Accepted: 25 March 2020 - Published: 21 April 2020

\begin{abstract}
Global climate change and the impacts of ocean warming, ocean acidification and declining water quality are adversely affecting coral-reef ecosystems. This is of great concern, as coral reefs provide numerous ecosystem, economic and social services. Corals are also recognised as being amongst the strongest individual sources of natural atmospheric sulfur, through stress-induced emissions of dimethylsulfide (DMS). In the clean marine boundary layer, biogenic sulfates contribute to new aerosol formation and the growth of existing particles, with important implications for the radiative balance over the ocean. Evidence suggests that DMS is not only directly involved in the coral stress response, alleviating oxidative stress, but also may create an "ocean thermostat" which suppresses sea surface temperature through changes to aerosol and cloud properties. This review provides a summary of the current major threats facing coral reefs and describes the role of dimethylated sulfur compounds in coral ecophysiology and the potential influence on climate. The role of coral reefs as a source of climatically important compounds is an emerging topic of research; however the window of opportunity to understand the complex biogeophysical processes involved is closing with ongoing degradation of the world's coral reefs. The greatest uncertainty in our estimates of radiative forcing and climate change is derived from natural aerosol sources, such as marine DMS, which constitute the largest flux of oceanic reduced sulfur to the atmosphere. Given the increasing frequency of coral bleaching events, it is crucial that we gain
\end{abstract}

a better understanding of the role of DMS in local climate of coral reefs.

\section{Introduction}

Tropical corals grow in warm, oligotrophic waters from approximately $30^{\circ} \mathrm{N}$ to $30^{\circ} \mathrm{S}$ (Fig. 1). This geographical restriction is due to the physiological requirements of reefbuilding Scleractinian corals which have relatively narrow thermal, light and salinity tolerance ranges (Bourne et al., 2016; Lesser, 2011; Hughes et al., 2018). The term coral holobiont refers to the symbiosis of the coral host with multiple endosymbiotic microorganisms including cyanobacteria, which aid in nitrogen fixation (Lesser et al., 2004), and photosynthetic dinoflagellates within the Symbiodiniaceae family (LaJeunesse et al., 2018; Muscatine and Porter, 1977). Several genera of Symbiodiniaceae may exist within the coral host depending on species and thermo-tolerance and are collectively termed zooxanthellae. These are acquired via phagocytosis and reside within membrane-enclosed compartments (the symbiosome) within the coral gastrodermis (Tresguerres et al., 2017). Zooxanthellae provide corals with their vibrant colours (e.g. Fig. 2) and $95 \%$ of their metabolic requirements via translocation of photosynthetically fixed carbon and, in return, depend upon the coral host to obtain inorganic carbon (Falkowski et al., 1984; Dubinsky and Falkowski, 2011). This symbiosis is essential for coral survival (Bourne et al., 2016). 


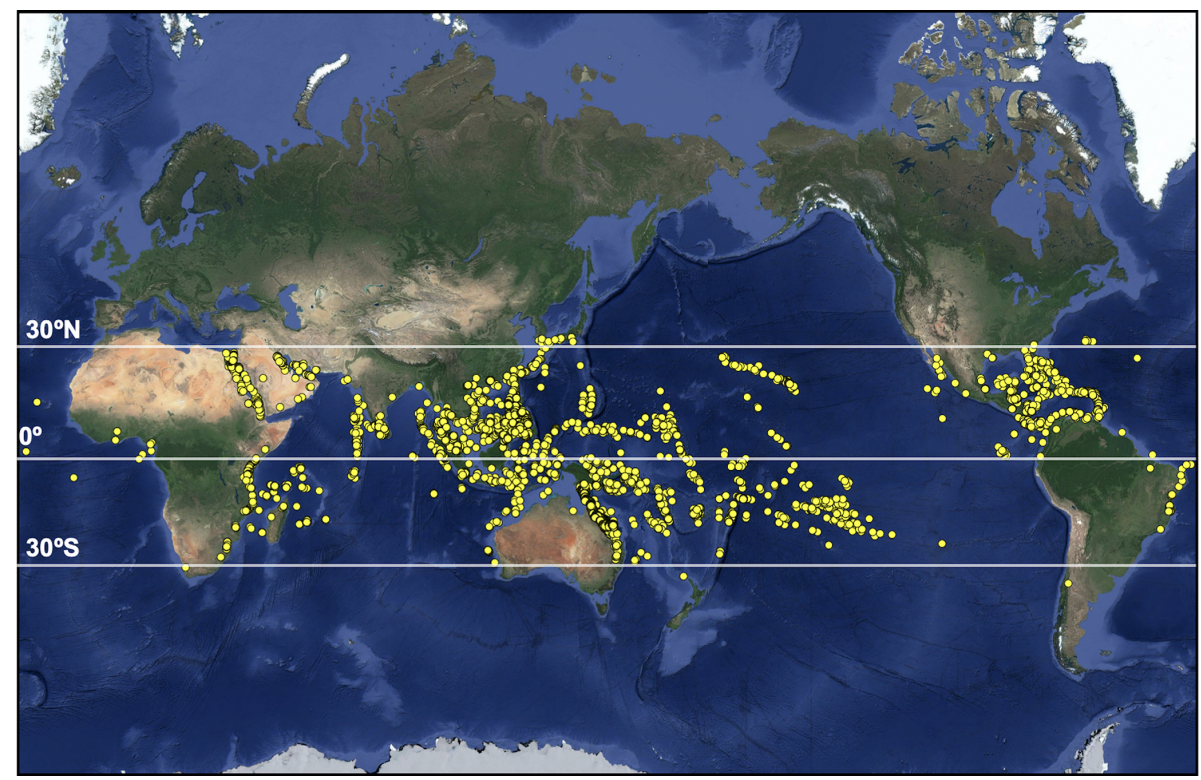

Figure 1. Global distribution of tropical coral reefs (map data @ 2019 Google). Locations provided by ReefBase (http://www.reefbase.org, last access: 16 July 2018).

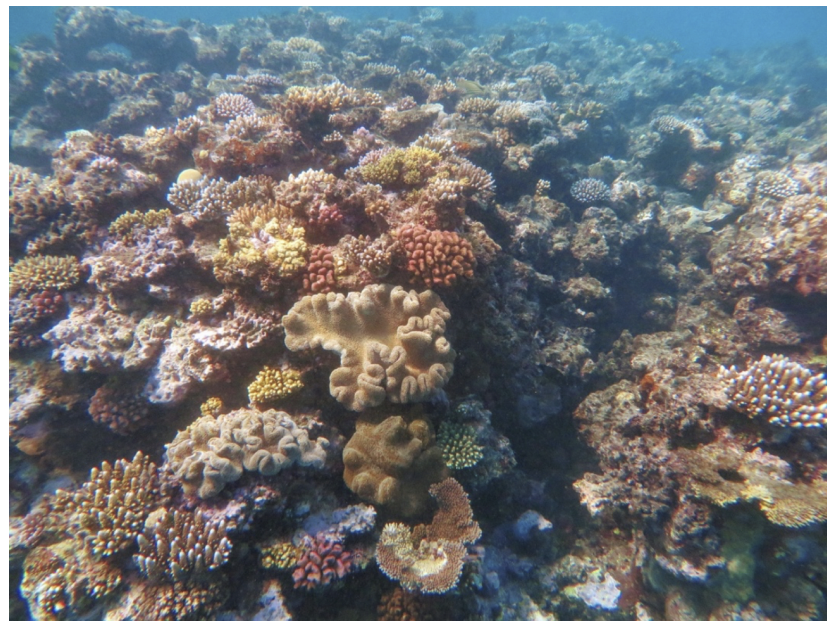

Figure 2. Diversity of corals at Norman Reef in the northern Great Barrier Reef, Australia (R. Jackson).

Shallow-water coral reefs cover only $0.1 \%$ $\left(\sim 600000 \mathrm{~km}^{2}\right)$ of the marine environment (Spalding et al., 2001) yet provide numerous essential ecosystem, economic and social services (Barbier et al., 2011; HoeghGuldberg et al., 2007; Jones, 2015), with an estimated value of USD 9.9 trillion annually (Costanza et al., 2014). Approximately one-third of all described marine species obtain their food and habitat from coral reefs (Reaka-Kudla, 1997). This biodiversity makes them hotspots for global tourism, providing approximately USD 36 billion annually (Spalding et al., 2017), and for the discovery of new medically important biochemical compounds (Kumar, 2006). The high productivity of coral reefs also provides a valuable source of income for global fisheries, estimated at USD 5.7 billion per year (Cesar et al., 2003). Fringing and barrier reefs are also highly effective at mitigating coastal erosion by reducing wave energy by up to $97 \%$ (Ferrario et al., 2014). Coral reefs provide many other services including nutrient cycling (Barbier et al., 2011; Gattuso et al., 1998; Bourne et al., 2016) and potentially climate regulation through stress-induced emissions of volatile sulfur compounds (Cropp et al., 2018; Fischer and Jones, 2012; Jones, 2015; Fiddes et al., 2018).

When corals experience physiological stress from high sea surface temperature (SST), irradiance, hyposalinity or exposure to air at low tide, they increase production of dimethylsulfoniopropionate (DMSP), which acts as an antioxidant for the coral holobiont (Deschaseaux et al., 2014a; Hopkins et al., 2016; Gardner et al., 2016). Depending on the degree of coral stress, a portion of DMSP is enzymatically cleaved to form the volatile gas dimethylsulfide (DMS; Raina et al., 2009; Bullock et al., 2017). Upon ventilation to the atmosphere, DMS is oxidised to form aerosol precursors (Andreae and Crutzen, 1997), which can affect aerosol and cloud properties (Sanchez et al., 2018; Charlson et al., 1987). DMS emissions from coral reefs may therefore exert a significant influence o $n$ local climate.

The role of coral reefs in climate has only recently begun to be appreciated, despite zooxanthellate corals being amongst the largest individual sources of biogenic sulfur in the marine environment (Burdett et al., 2015; Broadbent and Jones, 2004; Haydon et al., 2018; Swan et al., 2017a; Van Alstyne et al., 2009). However, our understanding of the bio- 
geochemical and ocean-atmosphere interactions involved in the coral-reef DMS cycle is not yet complete (Jones, 2015), contributing to the large uncertainty in the role of natural aerosols in our estimates of radiative forcing (Carslaw et al., 2013). The ongoing degradation of the world's coral reefs provides an urgency to gaining a better understanding of these processes. A concern is whether a decline in emissions of DMS-derived aerosol will alter the local radiative balance and accelerate warming in coral reefs, impeding the ability of corals to cope with future climate change. In this review we examine the role of DMS in coral ecophysiology and the emerging topic of coral reefs as a source of marine biogenic aerosol (MBA). The implications of coral bleaching and ongoing coral-reef degradation will also be discussed to highlight the importance of a multi-disciplinary approach to coral-reef management.

\section{The role of dimethylated sulfur compounds in coral reefs}

\subsection{The coral-reef sulfur cycle}

Scleractinian corals are recognised as being a significant source of DMS $(\mathrm{P})$, with reported concentrations of $54381 \mathrm{nmol}$ DMSP in a $50 \mathrm{~mL}$ sample of coral mucous ropes (Broadbent and Jones, 2004), 409-459 $\mathrm{nmol} \mathrm{DMSP} \mathrm{cm}^{-2}$ of coral surface (Frade et al., 2016; Hill et al., 1995, 2010) and $45.9 \mathrm{nmol} \mathrm{m}^{-3}$ atmospheric DMS (DMS ${ }_{\mathrm{a}}$ ) above a coral reef exposed to air at low tide (Swan et al., 2017a). In the coral-reef-dense region of the Indo-Pacific, Acropora spp. are abundant and contain the highest reported concentrations of DMS(P) amongst coral genera (Swan et al., 2017b), exceeding $3500 \mathrm{nmol} \mathrm{DMSP} \mathrm{cm}^{-2}$ (Broadbent et al., 2002). Other zooxanthellate organisms including octocorals (soft coral) and giant clams contain high amounts of DMSP, with concentrations of up to $4710 \mathrm{nmol} \mathrm{mg}^{-1}$ protein (Haydon et al., 2018) and $33000 \mathrm{nmol} \mathrm{g}^{-1}$ tissue (Hill et al., 2000), respectively. Concentrations in the coral holobiont and other zooxanthellate organisms are substantially higher than that reported for benthic macroalgae $\left(1.5 \mathrm{nmol} \mathrm{cm}{ }^{-2}\right)$ and individual free-living dinoflagellates $\left(1.5 \times 10^{-4} \mathrm{nmol}\right.$ per zooxanthellae cell; Broadbent et al., 2002).

In the coral holobiont, the biosynthesis of DMSP is upregulated in response to physiological stress. DMSP catabolism occurs via the cleavage and demethylation pathways, yielding DMS or methanethiol (MeSH), respectively (Fig. 3). The cleavage pathway is mediated by either DMSP-lyase enzymes, yielding DMS and acrylate (Bullock et al., 2017; Caruana and Malin, 2014; Raina et al., 2009), or via the addition of an acyl coenzyme A (encoded for by the microbial dddD gene) before cleavage to DMS occurs (Todd et al., 2007). The amount of DMS ultimately released to surrounding reef waters is dependent upon the ratio of DMSP breakdown to DMS and DMS(P) photo-oxidation to dimethyl sul- foxide (DMSO) by reactive oxygen produced by the coral holobiont under stress (Fig. 3). Although oxidation to DMSO is a sink of DMS(P), DMSO may also be reduced back to DMS and therefore also acts as a DMS source in coral-reef waters (Fischer and Jones, 2012; Gardner et al., 2016; Deschaseaux et al., 2014b). The physiological requirements of microbial communities within the coral host and in coral-reef waters also play an important role in the cycling of DMSP, switching between the DMSP cleavage and demethylation pathways (Fig. 3). Microbial cleavage of DMSP yields DMS (and acrylate via the DMSP-lyase cleavage pathway), which serves as an important carbon source, while the demethylation pathway yields an organic sulfur source for the coral microbiome (Bourne et al., 2016; Sun et al., 2016; Bullock et al., 2017).

DMSP is a zwitterion and will not diffuse across cell membranes. Corals expel their endosymbiotic microalgae at a rate of $0.2 \%-0.4 \%$ zooxanthellae cells per day in response to elevated irradiance or temperature (Jones et al., 2007). DMSP, in the form of dissolved $\left(\mathrm{DMSP}_{\mathrm{w}}\right)$ or particulate $\left(\mathrm{DMSP}_{\mathrm{p}}\right)$ DMSP, is instead released into surrounding waters from expelled zooxanthellae (Fig. 3) via natural cell senescence or grazing by zooplankton and herbivorous fish (Dacey and Wakeham, 1986). Dissolved DMS $\left(\mathrm{DMS}_{\mathrm{w}}\right)$ and dissolved DMSO $\left(\mathrm{DMSO}_{\mathrm{w}}\right)$ may also be released in zooxanthellae exudates or in coral mucous (Broadbent and Jones, 2006; Raina et al., 2009). DMS ${ }_{\mathrm{w}}$ is then ventilated to the atmosphere, where it has a residence time of approximately $1 \mathrm{~d}$ (Khan et al., 2016), before atmospheric reaction mechanisms such as oxidation to sulfur dioxide $\left(\mathrm{SO}_{2}\right)$ or methane sulfonic acid (MSA) occur (Andreae and Crutzen, 1997; Barnes et al., 2006; Veres et al., 2020).

Figure 4 provides a simplified overview of the role of dimethylated sulfur compounds in the DMS-aerosol-cloud feedback over coral reefs. When pre-existing aerosol concentrations and cloud cover are high, for example when high wind speeds enhance sea-spray aerosol (SSA) emission, heterogenous oxidation of DMS-derived sulfates occurs rapidly in cloud droplets, contributing to the growth of existing particles rather than the formation of new particles (Woodhouse et al., 2013; Hoffmann et al., 2016). Conversely, during calm, clear conditions, DMS-derived sulfates may undergo further oxidation to sulfuric acid $\left(\mathrm{H}_{2} \mathrm{SO}_{4}\right)$, followed by gaseousphase nucleation to form new non-sea salt sulfate $\left(\mathrm{nss}-\mathrm{SO}_{4}\right)$ particles (Fig. 4). Nucleation of $\mathrm{H}_{2} \mathrm{SO}_{4}$ may occur within the marine boundary layer (MBL) or in the free troposphere where conditions are more favourable, with entrainment providing an important source of new sulfate particles to the MBL (Sanchez et al., 2018). These secondary aerosols can be efficient cloud condensation nuclei $(\mathrm{CCN})$ and may affect cloud albedo, lifetime and cover over oceans (Charlson et al., 1987). 


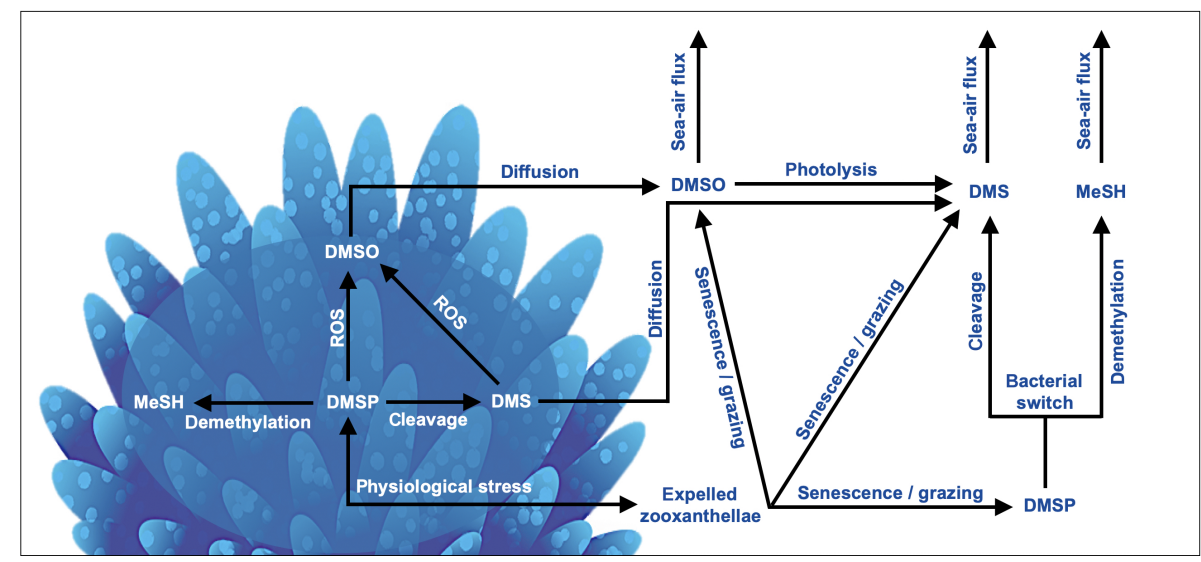

Figure 3. Basic processes involved in the cycling of dimethylated sulfur compounds involved in a coral reef. In corals, dimethylsulfoniopropionate (DMSP) is produced by both the coral host and endosymbiotic algae in response to physiological stress. DMSP catabolism occurs via the demethylation and cleavage pathways, yielding methanethiol (MeSH) or dimethylsulfide (DMS), respectively. DMS(P) scavenge reactive oxygen species (ROSs) produced in coral tissues and by zooxanthellae photosystems during exposure to high temperatures, irradiance and/or hyposalinity, forming dimethyl sulfoxide (DMSO). DMS $(\mathrm{P})(\mathrm{O})$ can be released to surrounding waters via zooxanthellae expulsion, followed by cell senescence and/or grazing by zooplankton or herbivorous fish. DMS(O) may also diffuse from the coral into surrounding waters. Dissolved DMSP may undergo microbial catabolism, yielding organic carbon or sulfur depending on bacterial needs (bacterial switch). DMS $(\mathrm{P})(\mathrm{O})$ may sink and become stored in sediment pore water. DMS $(\mathrm{O})$ may be ventilated to the lower atmosphere by wind- and temperature-driven transfer across the ocean-atmosphere interface.

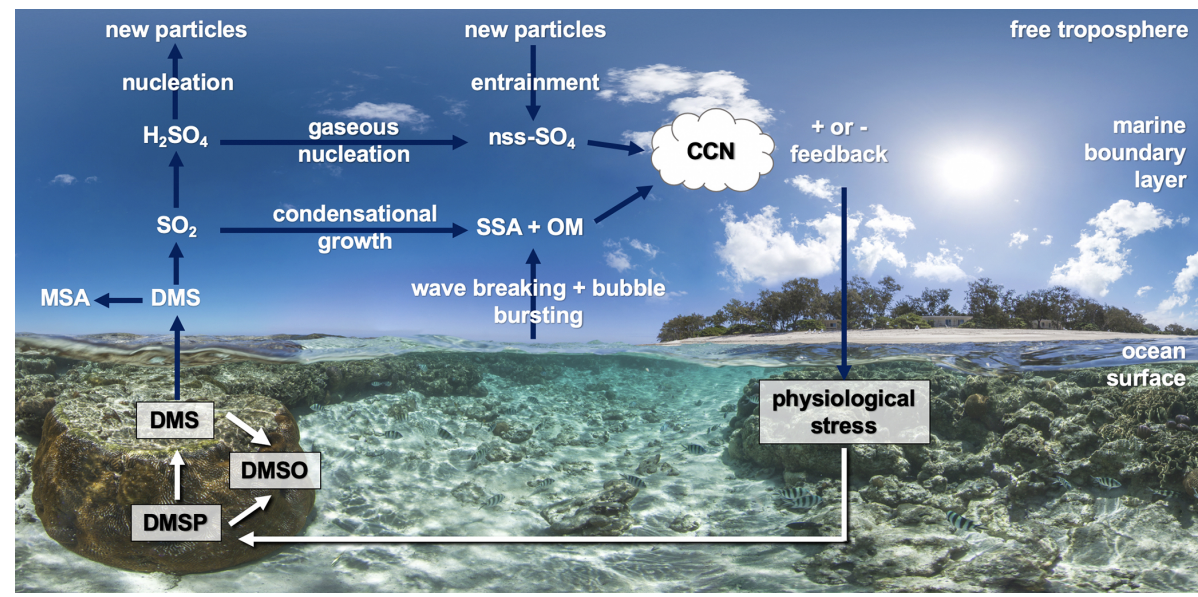

Figure 4. Simplified overview of the coral-reef DMS-aerosol-cloud feedback (DMS - dimethylsulfide). Dimethylsulfoniopropionate (DMSP) is produced by the coral holobiont and may be oxidised to dimethyl sulfoxide (DMSO) or cleaved to DMS. Atmospheric DMS is oxidised to sulfate aerosol precursor compounds including methane sulfonic acid (MSA) and sulfur dioxide ( $\left.\mathrm{SO}_{2}\right)$ and secondarily to sulfuric acid $\left(\mathrm{H}_{2} \mathrm{SO}_{4}\right)$, which may condense onto existing particles (e.g. sea-spray aerosol - SSA - or organic matter - OM) or nucleate to non-sea salt sulfate particles (nss- $\left.\mathrm{SO}_{4}\right)$. These may increase the number of cloud condensation nuclei $(\mathrm{CCN})$ and increase cloud lifetime and albedo. Background image: http://catlinseaviewsurvey.com/gallery/i853_lady-elliot-island-australia/ (last access: 2 March 2020), (C) Underwater Earth/XL Catlin Seaview Survey/Aaron Spence/CC BY-NC-SA 4.0.

\subsection{Mechanisms of biosynthesis}

The biochemical pathways involved in DMSP biosynthesis in corals are complex (Bullock et al., 2017). Until recently, it was thought that biosynthesis in the coral holobiont was limited to photosynthetic endosymbionts. However, recent findings show that coral hosts themselves are substantial sources of DMSP (Raina et al., 2013). In phytoplankton,
DMSP is produced via a series of four enzymes (Gage et al., 1997) which assimilate sulfur into cysteine and methionine and subsequently into the stable, soluble-form DMSP (Bourne et al., 2016; Stefels, 2000). Acropora spp. contain orthologues of genes responsible for the expression of two of these enzymes, which encode NADPH-reductase and AdoMet-dependent methyltransferase enzymes involved in the second and third steps of the DMSP biosynthesis path- 
way, respectively (Raina et al., 2013). The methyltransferase enzyme is particularly specific to this pathway and is highly expressed in Acropora juveniles which have not yet assimilated endosymbiotic Symbiodiniaceae. Expression declines with adult development likely due to coral association with zooxanthellae (Raina et al., 2013). Additionally, high levels of intracellular DMSP are reported in Acropora spp., with A. tenuis and A. millepora juveniles exhibiting $65 \%$ and $76 \%$ increases in DMSP concentration in response to thermal stress (Raina et al., 2013). Similar responses were observed in adult corals after exposure to temperatures of $32^{\circ} \mathrm{C}$ for $10 \mathrm{~d}$. Despite a decline in zooxanthellae density of $84 \%$ (where the remaining $16 \%$ were severely structurally compromised and not producing DMSP), DMSP concentration increased by $68 \%$, suggesting that the coral polyp was the source of biosynthesis (Raina et al., 2013).

There are a number of hypotheses as to why corals synthesise DMSP. Sulfur is an essential nutrient for all life forms, involved in amino acid and protein synthesis. Carbon is also an essential component of life, providing an energy source for respiration. DMSP provides an abundant organic source of both sulfur and carbon in coral reefs, and biosynthesis is thought to play a role in the structuring of the coral microbiome (Bourne et al., 2016; Raina et al., 2009, 2010). These endosymbionts provide a number of services to the coral host, including carbon and nitrogen fixation (Falkowski et al., 1984; Dubinsky and Falkowski, 2011) and disease prevention via production of antimicrobial compounds such as tropodithietic acid (TDA), derived from microbial DMSP catabolism (Raina et al., 2016). DMSP is also involved in alleviating oxidative stress in Scleractinian corals (Hopkins et al., 2016; Gardner et al., 2016; Deschaseaux et al., 2014b).

\subsection{The coral antioxidant response}

Empirical evidence shows that DMSP biosynthesis in Scleractinian corals is upregulated during periods of elevated SST, irradiance, aerial exposure at low tide, and hyposalinity associated with rainfall or fluvial discharges from adjacent river systems (Andreae et al., 1983; Swan et al., 2017a; Broadbent and Jones, 2006; Jones et al., 2007; Gardner et al., 2016; Hopkins et al., 2016; Raina et al., 2013). Corals and the endosymbiotic relationship they depend upon have a relatively narrow thermal, light and salinity tolerance range (Lesser, 2011; Nielsen et al., 2018). Enhanced production of dimethylated sulfur compounds when these tolerance ranges are approached suggests that DMSP may play a key role in the coral stress response. Strong production of DMS by corals exposed to air at low tide was first noted by Andreae et al. (1983) during ship measurements throughout the Florida Keys. Although $\mathrm{DMS}_{\mathrm{w}}$ production was dominated by benthic and planktonic algae, the coral reef became a much stronger source of DMS during low tide, with spikes in $\mathrm{DMS}_{\mathrm{a}}$ more than twice those of the background oceanic signal (Andreae et al., 1983). This was more recently observed in the Great Barrier Reef (GBR), Australia, where $\mathrm{DMS}_{\mathrm{a}}$ can exceed $45 \mathrm{nmol} \mathrm{m}^{-3}$ during low tide (Swan et al., 2017a). Field measurements show that DMSP and DMS are correlated with SST (Jones et al., 2007) and tide height (Jones and Trevena, 2005) throughout the GBR. This relationship has also been demonstrated in chamber experiments (Raina et al., 2013; Hopkins et al., 2016). For example, A. intermedia sampled from Heron Island in the southern GBR increased intracellular DMSP production by $45 \%$ in response to a $2{ }^{\circ} \mathrm{C}$ rise in ambient SST (Jones et al., 2014). Similarly, in Curaçao reef-building corals the biosynthesis of a number of betaines, including DMSP, is modulated by irradiance, indicating a role in photoprotection in the coral holobiont (Hill et al., 2010).

Elevated irradiance and/or SST can impair zooxanthellae photosystems, destabilising the photosynthetic electrontransport chain and increasing the production of harmful reactive oxygen species (ROSs; Lesser et al., 1990; Jones et al., 2002; Yakovleva et al., 2009; Downs et al., 2002). These ROSs can diffuse from the symbiosome into the coral gastrodermis, where antioxidant defences may prevent oxidative damage by reducing ROS levels to the tolerance threshold of the coral holobiont. In phytoplankton, superoxide dismutase (SOD) and glutathione interactions form an antioxidant pathway, whereby SOD converts superoxide anions to hydrogen peroxide $\left(\mathrm{H}_{2} \mathrm{O}_{2}\right)$ and oxygen $\left(\mathrm{O}_{2}\right)$ while the glutathione pathway regenerates the enzyme ascorbate peroxidase, responsible for scavenging $\mathrm{H}_{2} \mathrm{O}_{2}$ (Lesser, 2006). DMSP, DMS and acrylate are also capable of scavenging ROSs (Sunda et al., 2002) and may therefore form a similar antioxidant system in corals (summarised in Fig. 3). Furthermore, Curaçao corals contain high concentrations of other photoprotective betaines, with collective total concentrations ranging from 12 to $20 \mathrm{nmol} \mathrm{L}^{-1} 4$ (mean $75 \mathrm{nmol} \mathrm{L}^{-1}$ ) of coral tissue (Hill et al., 2010). Glycine betaine and proline betaine were the most prominent compounds in the sampled corals and may, too, increase the oxidative stress threshold of the coral holobiont.

The role of DMSP in the coral antioxidant response is supported by several studies which show that when stress exceeds coral physiological limits (e.g. SST $>30^{\circ} \mathrm{C}$, salinity $<24$ psu - psu: practical salinity units - or exposure to air at low tide), DMSP and DMS concentrations decline as the rate of oxidation to DMSO increases (Hopkins et al., 2016; Gardner et al., 2016; Deschaseaux et al., 2014b). For example, when Acropora spp. were exposed to SST $2{ }^{\circ} \mathrm{C}$ above the climatological summer maximum for a period of $36 \mathrm{~h}$, chamber headspace DMS concentrations declined by $93 \%$ as the ratio of dissolved DMSO to DMSP increased (Fischer and Jones, 2012). Similarly, increases in $\mathrm{DMS}_{\mathrm{a}}$ occur when corals are exposed to air at low tide due to direct atmospheric exchange (Swan et al., 2017a). DMS ${ }_{\mathrm{a}}$ declines with time as oxidation to DMSO increases. When corals are resubmerged, a second spike in $\mathrm{DMS}_{\mathrm{a}}$ occurs as the dissolution of DMS-rich coral mucous increases sea surface concentration and ventilation to the atmosphere. Atmospheric and dis- 
solved DMS levels then decline again as DMSO concentrations increase (Hopkins et al., 2016; Swan et al., 2016). This trend is also observed when corals are exposed to low salinity ( $\sim 16$ psu; Gardner et al., 2016), as occurs on inshore continental reefs during the wet season when fluvial discharge is high. The decline in intracellular DMSP and DMS emissions with high stress levels reflects enhanced photochemical oxidation to DMSO, suggesting that DMS(P) is a sensitive indicator of coral stress and an important antioxidant in the coral holobiont. As mentioned earlier, soft corals (e.g. Octocorallia spp.) contain large quantities of DMS(P). However, unlike Scleractinian corals, emissions of DMS from zooxanthellate soft corals do not vary seasonally, perhaps indicating an alternative ecological role involving holobiont community structuring (Haydon et al., 2018). Given the increasing dominance of soft corals in disturbed coral-reef systems (Inoue et al., 2013; Norström et al., 2009), a shift in coral community structure could lead to a significant change in DMS emissions from coral reefs.

\section{Environmental stressors and their impact on DMSP cycling}

A key question is how the DMS(P) antioxidant system in corals will respond to a changing climate and whether a change in DMS(P) synthesis facilitates or hinders corals' ability to adapt to rapid environmental change. Bourne et al. (2016) review the cumulative impacts of coral-reef stressors and claim that when temperature, ocean acidification, water quality and other stressors such as overfishing accumulate, the diversity and resilience of the coral microbiome and coral-reef ecosystem decline. Reduced diversity may lead to a higher risk of coral disease and mortality and widescale ecosystem shifts before a new stable state is achieved (Bourne et al., 2016). Figure 5 summarises the impacts of climate change and modification of land use on coral reefs and the possible impact on DMS emissions. However, the impacts of ocean warming, ocean acidification and declining water quality on net DMS production and sea-air flux in coral reefs remain uncertain.

\subsection{Ocean warming}

Ocean warming is considered to be one of the greatest threats to coral reefs (Baker et al., 2008; Heron et al., 2016; Hughes et al., 2018; Skirving et al., 2019). More than $90 \%$ of the heat energy accumulated in the Earth's climate system, largely a result of anthropogenic greenhouse gas (GHG) emissions, is stored in the ocean. Consequently, global mean SST has risen by $0.5^{\circ} \mathrm{C}$ over the last 40 years (IPCC, 2014). The stability of the coral system is dependent upon the range of temperature and irradiance experienced by the coral host and their endosymbionts (Dubinsky and Falkowski, 2011; Lesser, 2011). If thermal and/or irradiance stress induces the production of excess ROSs (Lesser, 2011), corals may change the composition of zooxanthellae clades (symbiont switching or shuffling) in an attempt to reduce oxidative stress (Bay et al., 2016) or expel their zooxanthellae, resulting in coral bleaching (Gates et al., 1992; Nielsen et al., 2018; Lesser et al., 1990). Temperature and irradiance stress can be exacerbated during exposure to air at low tide during the day, which can result in extensive partial mortality of intertidal corals (Buckee et al., 2019). The severity of coral bleaching and subsequent mortality is dependent on the magnitude of stress and duration of exposure (Ainsworth et al., 2016).

As many Scleractinian corals now reside in regions with SST close to their upper physiological limits, a $0.5^{\circ} \mathrm{C}$ rise in SST above the local summer maximum for a period of several weeks is sufficient to cause coral bleaching and mortality (Berkelmans, 2009). SST greater than $\sim 2{ }^{\circ} \mathrm{C}$ above the summertime maximum can result in coral bleaching over much shorter timescales, depending on coral tolerance to thermal and/or irradiance stress and on the magnitude and duration of exposure (Bainbridge, 2017). If stress levels subside quickly, corals may regain their zooxanthellae and recover, although surviving corals can have reduced growth, calcification and reproductive rates and a higher incidence of disease and competitive susceptibility (Baker et al., 2008; Ward et al., 2002; Chaves-Fonnegra et al., 2018). Recent work found an $89 \%$ decline in larval recruitment during the 2018 spawning event in the GBR after consecutive mass bleaching events adversely affected populations of adult spawning corals (Hughes et al., 2019). If current GHG emissions continue, it is estimated that $50 \%$ of coral reefs will experience annual severe coral bleaching by 2030 and more than $95 \%$ by 2050 (Burke et al., 2011), assuming corals cannot adapt or acclimate to the changing climate.

Empirical evidence has demonstrated that DMS(P) biosynthesis is upregulated during thermal stress, followed by oxidation to DMSO in temperature-sensitive species (e.g. Deschaseaux et al., 2014a). Therefore, warmer oceans will likely cause an upregulation of DMSP biosynthesis and oxidation to DMSO in coral reefs (Fig. 5). However, variation among coral species and zooxanthellae type and their interactions with marine macro- and microalgae will govern changes to the coral-reef sulfur cycle. When corals experience thermal stress, Acropora spp. in the GBR have been found to expel thermo-sensitive clade C Symbiodiniaceae, instead taking up the more tolerant clade $\mathrm{D}$ variety (Bay et al., 2016). Coral switching and/or shuffling of endosymbionts may occur rapidly over timescales of several days to weeks or occur gradually over several months in response to changes in environmental conditions. Changing their endosymbiont community structure to favour more tolerant species can assist corals in coping with physiological stress, as thermo-tolerant zooxanthellae photosystems do not produce an excess amount of ROSs. For example, symbiont shuffling to favour type $\mathrm{D}$ symbiont dominance in A. millepora increased thermo-tolerance by $\sim 1.5^{\circ} \mathrm{C}$ (Berkelmans 


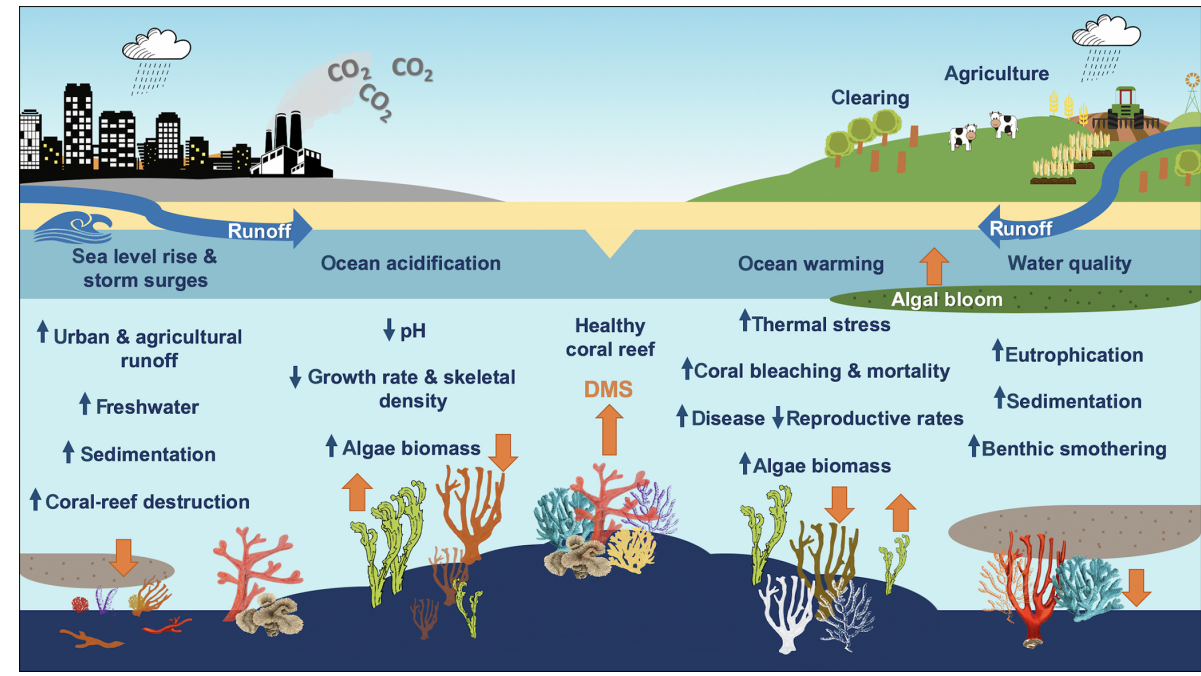

Figure 5. The impacts of climate change and land use on coral reefs. Orange arrows reflect the predicted increase or decrease in DMS emissions from the coral holobiont and marine micro- and macroalgae.

and Van Oppen, 2006). Interestingly, temperature-tolerant zooxanthellae clades (e.g. clade D) produced less DMSP compared to temperature-sensitive clades when exposed to the same conditions (Deschaseaux et al., 2014b; Bay et al., 2016), likely reflecting differences in thermo-tolerance. However, tolerance thresholds within zooxanthellae clades are highly variable (Klueter et al., 2017) and do not always predict DMSP biosynthesis (Steinke et al., 2011).

Marine micro- and macroalgae compete with corals for light, nutrients and space. When coral reefs are degraded by coral bleaching, fleshy macroalgae such as Polysiphonia spp. and Ulva spp., which also synthesise DMSP (Van Alstyne and Puglisi, 2007), may dominate (De'ath and Fabricius, 2010; Bell, 1992; McClanahan et al., 2011; McCook and Diaz-Pulido, 2002). Phytoplankton blooms, which are additional sources of DMSP in coral reefs, have been positively correlated with aerosol concentration in the Southern Ocean, reflecting an enhanced biogenic particle source from DMS and other organic emissions (Korhonen et al., 2008; McCoy et al., 2015). This additional algal source of biogenic sulfur may counteract any decline in coral emissions (Fig. 5). Algal blooms may also increase light attenuation at the surface, alleviating coral light stress; however, these organisms also promote heat absorption at the ocean surface, converting $\sim 60 \%$ of absorbed photons to heat (Lin et al., 2016). Therefore, increasingly algae-dominated coral-reef communities may exacerbate the warming effects of GHGs in coral reefs.

\subsection{Ocean acidification}

Ocean acidification (OA) affects coral reefs by enhancing dissolution and limiting $\mathrm{pH}$-sensitive coral calcification rates (Tresguerres et al., 2017; Albright et al., 2018; Steiner et al.,
2018). Anthropogenic carbon dioxide $\left(\mathrm{CO}_{2}\right)$ emissions are $10.1 \pm 0.5 \mathrm{Gt} \mathrm{C} \mathrm{yr}^{-1}$ (Le Quéré et al., 2018), of which approximately $30 \%$ is absorbed by the oceans and affects seawater chemistry (IPCC, 2014; Orr, 2011). Increased $\mathrm{CO}_{2}$ levels enhance the formation of carbonic acid $\left(\mathrm{H}_{2} \mathrm{CO}_{3}\right)$, which readily dissociates into bicarbonate ions $\left(\mathrm{HCO}_{3}^{-}\right)$and protons $\left(\mathrm{H}^{+}\right)$as per Eq. (1). These protons react with carbonate $\left(\mathrm{CO}_{3}^{2-}\right)$ to produce more $\mathrm{HCO}_{3}^{-}$ions, which, in turn, decrease the bioavailability of $\mathrm{CO}_{3}^{2-}$ for marine calcification (Orr, 2011). The current concentration of $\mathrm{CO}_{3}^{2-}$ ions in the ocean is $200 \mu \mathrm{mol} \mathrm{kg}^{-1}$ of seawater (Zeebe and Tyrrell, 2019), around $40 \mu \mathrm{mol} \mathrm{kg}^{-1}$ less than the minimum over the past 420000 years (Hoegh-Guldberg et al., 2007). OA also favours erosion of calcareous structures (Eq. 2), with massive Porites corals in the northern GBR displaying annual declines in linear extension rates and skeletal density of $1.02 \%$ and $0.36 \%$ respectively (Cooper et al., 2008). If current GHG emissions persist, it is estimated that less than $15 \%$ of the world's tropical coral reefs will be in regions with carbonate saturation sufficient for coral growth by 2050 (Burke et al., 2011):

$$
\begin{aligned}
\mathrm{CO}_{2(\mathrm{~g})}+\mathrm{H}_{2} \mathrm{O}_{(\mathrm{l})} & \Leftrightarrow \mathrm{H}_{2} \mathrm{CO}_{3(\mathrm{aq})} \Leftrightarrow \mathrm{HCO}_{3(\mathrm{aq})}^{-}+\mathrm{H}_{(\mathrm{aq})}^{+} \\
& \Leftrightarrow \mathrm{CO}_{3(\mathrm{aq})}^{2-}+2 \mathrm{H}_{(\mathrm{aq})}^{+}, \\
\mathrm{CaCO}_{3(\mathrm{~s})}+2 \mathrm{H}_{(\mathrm{aq})}^{+} & \Leftrightarrow \mathrm{Ca}_{(\mathrm{aq})}^{2+}+2 \mathrm{HCO}_{3(\mathrm{aq})}^{-} .
\end{aligned}
$$

It is unclear how DMSP cycling will be influenced by OA, and this is particularly true of coral reefs. In remote oceans such as the Arctic, biosynthesis of DMSP is predicted to increase due to enhanced phytoplankton biomass and availability of inorganic carbon (Archer et al., 2013). Other studies predict that the flux of DMS to the atmosphere will decrease due to a decline in the abundance of DMSP producers such as 
phytoplankton (Schwinger et al., 2017; Archer et al., 2018). Regardless, acidification appears to be adversely affecting coral calcification and health (Cooper et al., 2008; HoeghGuldberg et al., 2007; Orr, 2011; Albright et al., 2018). If this continues, a decline in coral cover may result in a decline in DMS emissions from coral reefs (Fig. 5). Again, opportunistic growth of marine algae is predicted to dominate degraded coral-reef systems (De'ath and Fabricius, 2010; Brodie et al., 2011; McCook and Diaz-Pulido, 2002). It is possible that increased DMS emissions from this algal source may counteract the decline in coral emissions (Fig. 5). However, recent evidence from the southern GBR demonstrated that the combined effects of ocean warming and acidification under RCP8.5 conditions (an IPCC representative concentration pathway - RCP - whereby GHG and aerosol emissions drive an $8.5 \mathrm{~W} \mathrm{~m}^{-2}$ increase in radiative forcing by 2100 ) also impaired calcification in the macroalga Halimeda heteromorpha (Brown et al., 2019). Other studies have demonstrated that temperature has a stronger influence on DMS(P) production in cultured microalgae, whereby increased production in response to temperature outweighed the decline in DMS(P) biosynthesis due to OA (Arnold et al., 2013).

\subsection{Water quality and eutrophication}

Declining water quality is another cause of coral-reef degradation. Although inner-shelf coral reefs exposed to reduced water quality are more resistant to coral bleaching, resilience is low due to increased susceptibility to disease and predation (MacNeil et al., 2019). Eutrophication arises when enhanced loading of the limiting macro-nutrients nitrogen $(\mathrm{N})$ and/or phosphorous $(\mathrm{P})$ induce excessive growth of marine algae (Howarth et al., 2011; Diaz and Rosenberg, 2008; McEwan et al., 1998), which impede coral growth and reduce the opportunity for new corals to establish (De'ath and Fabricius, 2010; Bell, 1992; McClanahan et al., 2011). This is often caused by catchment runoff and soil erosion from land clearing, agriculture and urbanisation (Brodie et al., 2011; McKergow et al., 2005). Resulting algal blooms can reduce water clarity, deplete dissolved oxygen and release toxins (Osborne et al., 2001), all of which adversely affect coral health and grazing fish populations. Depletion of grazing fish populations further favours algal growth by removing top-down control (McClanahan et al., 2011). Eutrophication leading to an increase in phytoplankton standing stock also contributes to outbreaks of Acanthaster planci (crown-of-thorns sea star), an invasive predator of corals and a significant threat to coral reefs (Fabricius et al., 2010; De'ath et al., 2012; Wooldridge and Brodie, 2015). These impacts are compounded by enhanced sedimentation from riverine discharge and dredging, which cause benthic smothering, increased turbidity and reduced light penetration, all of which adversely affect photosynthesising organisms, including coral zooxanthellae (Erftemeijer et al., 2012). Sealevel rise and changes to large-scale oceanic circulation in re- sponse to global warming exacerbate coastal erosion, which contributes to declining water quality. Climate change has also caused an increase in storm surges which further degrade coral reefs (Mellin et al., 2019). Measurements of dissolved DMS(P) have been found to decline along a gradient of relatively pristine to human-impacted coral reefs in the central GBR (Jones et al., 2007). However, it is unclear whether poor water quality will result in a net decline in DMS flux from coral reefs in future, as an enhanced algal source may counteract declining emissions from corals (Fig. 5).

\section{Marine biogenic aerosols}

\subsection{The CLAW hypothesis}

The CLAW hypothesis (1987) proposed that marine DMS emissions increase the formation of low-level, high-albedo cloud cover, establishing a biologically derived negative feedback on the warming effects of GHG (Charlson et al., 1987; Shaw, 1983). Despite decades of research, our knowledge of the biological, chemical and atmospheric processes involved in the biosynthesis, flux and climatic influences of DMS remains incomplete. Some suggest that the original hypothesis is an oversimplification (Green et al., 2014) or no longer relevant (Quinn and Bates, 2011) due to anthropogenic perturbation of the atmosphere throughout much of the globe (Spracklen and Rap, 2013). However, others remain steadfastly positive about the role of DMS in global climate (Grandey and Wang, 2015).

\subsection{DMS sea-to-air flux}

The global sea-air flux of DMS is estimated to be 17.634.4 $\mathrm{Tg} \mathrm{S} \mathrm{yr}^{-1}$ (Kettle and Andreae, 2000; Lana et al., 2011; Land et al., 2014), accounting for approximately $50 \%$ of the natural global atmospheric sulfate burden (Bates et al., 1992; Simó, 2001; Barnes et al., 2006). The large DMS flux range reflects the uncertainty in undersampled ocean regions where newly collected data improve the estimate (Webb et al., 2019). Emissions are highly variable in both space and time and are primarily governed by ocean biology in the middlelow-latitude oceans (Broadbent and Jones, 2006; Jones et al., 2007; Korhonen et al., 2008) and sea-ice dynamics in polar regions (Gabric et al., 2018). The sea-to-air flux of DMS depends on its surface ocean concentration (Lana et al., 2011), SST (Yang et al., 2011), wind speed (Ho and Wanninkhof, 2016), and water depth or tide height (Swan et al., 2017a). Higher sea surface DMS concentration, SST and wind speed (which increase diffusivity), and reduced tide height will enhance the sea-air flux of DMS in coral-reef waters.

It is unclear how marine DMS production and sea-air flux will change in response to climate change. In the Arctic, DMS flux is estimated to increase by $86 \%$ to $300 \%$ under modelled scenarios of 3 to 4 times present-day $\mathrm{CO}_{2}$ concentrations. This predicted increase is due to a combination 
of enhanced biological activity and changes to sea-ice dynamics (Gabric et al., 2005; Qu et al., 2017). On a global scale, atmospheric DMS concentrations are predicted to increase by $41 \%$ with a tripling of atmospheric $\mathrm{CO}_{2}$, increasing mean aerosol optical depth (AOD) by $3.5 \%$ and cooling the Northern and Southern Hemisphere by 0.4 and $0.8 \mathrm{~K}$, respectively (Gabric et al., 2013). Other studies simulate a global reduction of the DMS flux by $10 \%-18 \%$ (Kloster et al., 2007; Six et al., 2013) and $48 \%$ (Schwinger et al., 2017) under various ocean acidification scenarios by the end of the 21st and 22nd centuries, respectively. Modelled scenarios predict an additional global warming of $0.23-0.48 \mathrm{~K}$ due to a decline in DMS-derived sulfate aerosols and cloud albedo (Schwinger et al., 2017; Six et al., 2013), although significant regional variability in the response of DMS emissions to climate perturbations was present. In the Southern Ocean, DMS emissions increased in response to warming, counteracting the predicted regional decrease in emissions in response to OA (Schwinger et al., 2017). This regional variability is likely driven by differences in carbonate chemistry and conditions to which phytoplankton communities are adapted, which play an important role in phytoplankton community structure and DMS production (Hopkins et al., 2020). Overall, studies from the last few decades of global biogeochemical modelling and mesocosm experiments provide both negative and positive changes in DMS flux under future climate conditions and highlight the need for an improved understanding of regional biogeochemical responses to climate change. This is particularly true of coral reefs, where few studies have attempted to quantify DMS emissions under current or future climate conditions.

The total contribution of coral reefs to the global sulfur budget is not yet clear; however, the GBR and lagoon waters $\left(347000 \mathrm{~km}^{2}\right.$ ) are estimated to emit $0.02 \mathrm{Tg} \mathrm{S} \mathrm{yr}^{-1}$ (Jones et al., 2018). It is noted that coral cover in the GBR is $20000 \mathrm{~km}^{2}$ and, consequently, DMS flux from the surrounding lagoon would appear to be higher than estimates from the coral reef. Sources of DMS in lagoon waters include phytoplankton, macroalgae and dissolved DMS released from the coral holobiont and other zooxanthellate organisms. Therefore, the total DMS flux can be considered an estimate of coral-reef DMS emissions. This is the first estimate of DMS flux from the GBR; however it is based on a limited number of field observations and does not account for occasional large pulses of DMS emitted by corals during aerial exposure at low tide (Swan et al., 2017a). When these events are considered, DMS sea-air flux from coral reefs would periodically increase. Hopkins et al. (2016) provided an estimate of DMS flux per unit area of the GBR, based on laboratory measurements taken from $A$. horrida periodically exposed to air. As Acropora are the dominant genus throughout the Indo-Pacific and are amongst the strongest producers of DMS(P), it was estimated that corals in the GBR release $3-11 \mathrm{mmol} \mathrm{S} \mathrm{m}^{-2} \mathrm{~d}^{-1}$. According to this estimate the GBR releases $0.01-0.04 \mathrm{Tg} \mathrm{S} \mathrm{yr}^{-1}$, consistent with the esti- mate provided by Jones et al. (2018). Assuming that DMS flux is constant across coral reefs and lagoon waters, tropical coral reefs $\left(\sim 600000 \mathrm{~km}^{2}\right)$ emit $0.02-0.08 \mathrm{Tg} \mathrm{S} \mathrm{yr}^{-1}$. Although this represents $<1 \%$ of global or tropical average DMS sea-air flux estimates (Lana et al., 2011), it is a substantial amount of sulfur released from only $0.2 \%$ of the ocean surface, with the potential to influence local climate in coral reefs.

\subsection{Complexity of the climate response to DMS}

Once ventilated to the atmosphere, the influence of DMS on climate is dependent on the efficiency of DMS oxidation to $\mathrm{SO}_{2}$ and secondarily to $\mathrm{H}_{2} \mathrm{SO}_{4}$ (Barnes et al., 2006), which ranges from 0.14 to 0.95 in the MBL due to spatiotemporal variation in pre-existing atmospheric properties (von Glasow and Crutzen, 2004). The annual mean contribution of DMS to CCN is estimated to be only $3.3 \%$ in the Northern Hemisphere and $9.9 \%$ in the Southern Hemisphere (Woodhouse et al., 2010). Consequently, the sensitivity of CCN to DMS emissions on a global scale is low, with a $1 \%$ increase in global DMS flux resulting in only a $0.1 \%$ increase in mean CCN (Woodhouse et al., 2010). Although the response of CCN to DMS is low on a global scale, spatial and seasonal estimates vary, with higher responses evident in pristine regions of high biological activity (Woodhouse et al., 2013; Lana et al., 2012; Vallina et al., 2007; Zavarsky et al., 2018). However, an alternate DMS oxidation pathway, involving the formation of hydroperoxymethyl thioformate (HPMTF), was recently observed in the marine atmosphere and accounts for $\sim 30 \%$ of oceanic DMS oxidation, with important implications for the representation of DMS-derived sulfates in atmospheric models (Veres et al., 2020). Further, models may underestimate DMS emissions in some parts of the ocean due to sparsity in global observations, resulting in large uncertainties in interpolated flux estimates (Mulcahy et al., 2018).

In the remote MBL, biogenic aerosols such as DMSderived sulfates may be important in smaller-scale climate regulation. Vallina et al. (2007) identified a strong sensitivity of the fine-mode AOD and $\mathrm{CCN}$ number to the rate of $\mathrm{DMS}_{\mathrm{a}}$ oxidation in pristine, high-latitude regions. In the North Atlantic, new sulfate particles formed via the nucleation of DMS-derived $\mathrm{H}_{2} \mathrm{SO}_{4}$ in the free troposphere accounted for $33 \%$ of $\mathrm{CCN}$ at $0.1 \%$ supersaturation, largely due to enhanced phytoplankton biomass in spring (Sanchez et al., 2018). Similarly, in the Southern Ocean, seasonal variability in cloud droplet number is primarily driven by changes in sea spray, organic matter and biogenic sulfates, with seasonal maxima during spring and summer, coinciding with enhanced biological activity and DMS emissions. DMSderived nss- $\mathrm{SO}_{4}$ particles account for $7 \%-20 \%$ of mean $\mathrm{CCN}$ in winter and $43 \%-65 \%$ in summer (Korhonen et al., 2008), increasing the Southern Ocean summertime mean reflectivity by more than $10 \mathrm{~W} \mathrm{~m}^{-2}$ (McCoy et al., 2015). Conversely, complete removal of DMS resulted in a modelled 
top-of-atmosphere radiative forcing of $+1.7 \mathrm{~W} \mathrm{~m}^{-2}$ (Fiddes et al., 2018).

\section{Do coral reefs affect the climate?}

The GBR provides a valuable study location for the analysis of biogenic aerosols. Given its large spatial extent $(2300 \mathrm{~km}$ in length and 60-250 km in width) and Southern Hemisphere location, the atmosphere over the GBR is considered to be relatively unpolluted. The region also experiences predominant east to south-easterly trade winds year-round, which carry clean, marine air to the GBR and advect biogenic compounds northward over downwind coral reefs. Consequently, the majority of research examining the role of coral reefs in MBA production has focused on the GBR region.

\subsection{Influence on particle formation and growth}

The ability of corals to influence local atmospheric properties has only recently begun to be appreciated. Bigg and Turvey (1978) measured total atmospheric particle concentration along the north-eastern Queensland (QLD) coastline from 1974 to 1977 and found that concentrations were up to 7 times higher in maritime air directly over the GBR compared to the seaward side. Three decades later, Leck and Bigg (2008) observed fluctuations in particle concentration at Lizard Island in the northern GBR during September 1998 and July 2005. Nucleation events forming particles with a diameter greater than $>0.01 \mu \mathrm{m}$ were observed on all study days, with concentrations reaching $40000 \mathrm{~cm}^{-3}$ during the warmer September period and up to $4300 \mathrm{~cm}^{-3}$ in July (Leck and Bigg, 2008). There is strong seasonality in both DMS (Jones et al., 2018; Swan et al., 2017a) and AOD in the GBR (Cropp et al., 2018; Jackson et al., 2018). The large seasonal difference in aerosol loading implies a temperature- or irradiance-dependent biological influence. Furthermore, Modini et al. (2009) observed nucleation events at Agnes Water in the southern GBR, in which corals were concluded to be the most likely source of precursor compounds. These events occurred in clean, easterly air masses originating in the MBL, when solar irradiance at the sea surface was high $\left(\sim 1000 \mathrm{~W} \mathrm{~m}^{-2}\right)$. Particles consisted of $40 \%$ organics and $60 \%$ sulfate. In the strongest nucleation event, Aitken mode $(<0.1 \mu \mathrm{m}$ in diameter) concentration was measured at $3200 \mathrm{~cm}^{-3}$. This event occurred during a NNE wind, accumulating particles of marine origin from upwind coral reefs. The authors concluded that Aitken mode concentration was too low to have been derived from coagulation alone; thus new particles were largely derived from the condensation of low-volatility vapours such as DMS-derived $\mathrm{H}_{2} \mathrm{SO}_{4}$ (Modini et al., 2009). Swan et al. (2016) also measured high particle concentration over Heron Island in the southern GBR, which coincided with a peak in DMS emissions from the coral-reef flat during calm conditions after a low tide, again suggesting that the coral reef was a source of MBA precursor compounds.

The ability of corals to influence the atmosphere above them has also been investigated using remote-sensing approaches. Lana et al. (2012) found that sulfate aerosols positively correlated with $\mathrm{CCN}$ and negatively correlated with cloud droplet radius throughout the mid- to high-latitude oceans and in some tropical latitudes, where a high density of coral reefs exists. Observations of satellite-derived finemode aerosol over parts of the GBR show concentrations to be positively correlated with conditions that are empirically shown to cause a stress response in corals and, thus, enhance DMS emissions (Cropp et al., 2018; Jackson et al., 2018). Correlation strength between aerosol and coral light stress (a function of PAR, tide height and water clarity) improved with decreasing wind speed at Heron Island, suggestive of a substantial local MBA source over the southern GBR (Cropp et al., 2018).

Figure 6 shows the seasonal zonally averaged variation in daily-mean (2001-2017) total AOD (869 nm) over the GBR, highlighting the seasonality in aerosol loading. These data were acquired at $4 \mathrm{~km}$ resolution from the Moderate Resolution Imaging Spectroradiometer (MODIS) aboard the Terra and Aqua satellites (https://oceancolor.gsfc.nasa.gov/, last access: 25 May 2019). Observations over the Australian continent were excluded; thus Fig. $6 \mathrm{~b}$ shows only zonally averaged AOD for the GBR and adjacent Coral Sea (Fig. 6a). In the northern half of the GBR, AOD is highest during the winter dry season (May-October). Conversely, the southern half of the GBR displays a marked increase in AOD during the warmer months (November-April) and a decrease in winter (Fig. 6b). It is not clear what is driving this latitudinal variability; however emissions of DMS and other volatile organic compounds (VOCs) such as isoprene cannot be excluded as a potential driver of seasonal variability. Existing research has linked seasonal variability in aerosol and $\mathrm{CCN}$ formation to enhanced biological activity in other remote ocean regions (Gabric et al., 2018; Korhonen et al., 2008). The increase in AOD during summer in the southern GBR is also suggestive of a temperature- or light-dependent biogenic influence, potentially from the high biomass of coral reefs below.

\subsection{Influence on low-level clouds, sea surface temperature and surface solar radiation}

The western Pacific warm pool (WPWP) is a coral-reefdense region located to the north-east of Australia, where SST reaches an upper limit of $\sim 30^{\circ} \mathrm{C}$ due to regular pulses of low-level cloud (LLC) cover which closely follow the tidal cycle (Kleypas et al., 2008; Takahashi et al., 2010; Ramanathan and Collins, 1991). It has been posited that coral-reef DMS emissions contribute to the formation of this "ocean thermostat", acting to suppress ocean temperatures below coral thermal tolerance thresholds, resulting in few coral bleaching events over the past 25 years (Kleypas et al., 


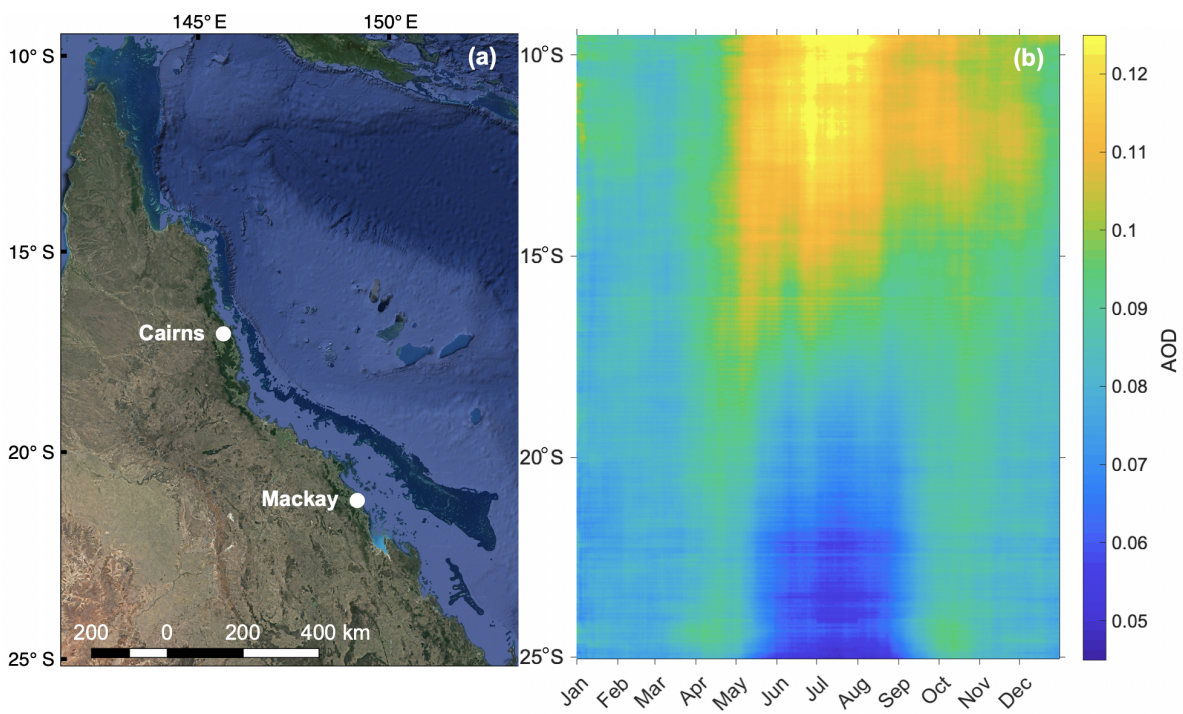

Figure 6. (a) Map of the GBR, Australia (map data (C) 2019 Google), showing the region defined in (b) longitude-averaged Hovmöller plot of daily mean (2001-2017) total AOD (869 nm) over the GBR.

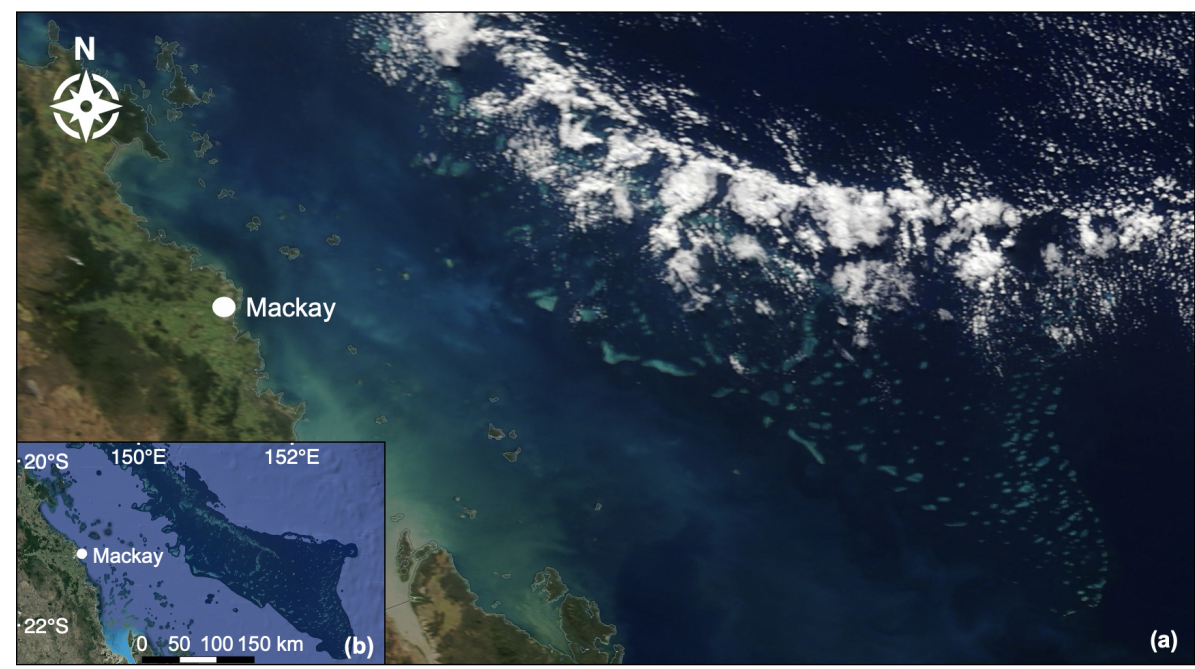

Figure 7. (a) Low-level convective clouds aligned over the Swain Reefs in the Mackay-Capricorn Management Area of the southern GBR. True-colour image captured by MODIS Terra on 31 May 2018 (NASA Earth Observing System Data and Information System). (b) Map of the southern GBR shown to be covered by clouds in the true-colour image (map data @ 2019 Google).

2008; Takahashi et al., 2010). Similarly, although an overall warming trend is apparent along the NE coast of Australia, SST in the far northern GBR is warming at a slower rate compared to southern regions (Lough, 2008; Heron et al., 2016). As in the WPWP, this is potentially due to enhanced LLC, which is estimated to account for approximately $30 \%$ of the variance in SST over the GBR (Leahy et al., 2013). Figure 7 shows LLC closely aligned over the Swain Reefs in the southern GBR, captured by MODIS Terra on 31 May 2018. Back trajectories computed by the National Oceanic and Atmospheric Administration (NOAA) Air Resources Laboratory HYSPLIT model show dominant south-westerly winds on this day (Stein et al., 2015; Rolph et al., 2017), potentially explaining the north-eastward migration of LLC in the true-colour image (Fig. 7).

Reduced SST and irradiance due to enhanced LLC have also been observed to mitigate mass coral bleaching events. For example, high SST in the summer of 1998 resulted in widespread coral bleaching throughout the tropics (Wilkinson et al., 1999). This event caused severe bleaching and subsequent mortality of $99 \%$ of Pocillopora corals in the Tuamotu Archipelago, French Polynesia (Mumby et al., 2001a). However, high LLC cover significantly reduced the amount of surface solar radiation at coral reefs in the nearby So- 
ciety Islands, where bleaching did not occur (Mumby et al., 2001b). Similarly, high SST $\left(>31^{\circ} \mathrm{C}\right)$ in 1994 caused coral bleaching at Nelly Bay (Magnetic Island) in the central GBR (Jones et al., 1997); however, no bleaching was observed $\sim 60 \mathrm{~km}$ away at Pioneer Bay (Orpheus Island; Jones et al., 2007). Jones et al. (2017) examined DMS a before, during and after this bleaching event at both locations. At the unbleached reef, regular pulses of LLC often coincided with pulses of DMS $\left(14-20 \mu \mathrm{mol} \mathrm{m}^{-2} \mathrm{~d}^{-1}\right)$. Conversely, at the bleached reef LLC cover and DMS emissions were low when SST exceeded $30^{\circ} \mathrm{C}$ (Jones et al., 2007) and coincided with high solar irradiance (Jones et al., 2017). Together these findings suggest that stress-induced emissions of DMS from coral reefs may influence local LLC cover to mitigate stress and prevent coral bleaching. However, spatial variation in this phenomenon is apparent, possibly due to prevailing meteorological conditions or other factors affecting coral-reef health as discussed in Sect. 2.

\subsection{Influence on precipitation}

Coral-reef-derived aerosol emissions have also been proposed to affect precipitation patterns. Jones (2015) discusses high rainfall in regions lying in the path of SE trade winds travelling over the GBR, implying that emissions of DMS and other organic compounds from the coral reef contributed to cloud droplet formation. Conversely, Fiddes et al. (2018) found that DMS-derived sulfate particles enhanced LLC cover and lifetime and consequently suppressed rainfall in parts of the tropics. When high concentrations of fine particles rapidly grow to $\mathrm{CCN}$ activation sizes, cloud droplet size decreases, cloud lifetime increases and rainfall is suppressed (Rosenfeld et al., 2007; Dave et al., 2019; Singh et al., 2018). However, when CCN minimum size is not met, water vapour remains in the atmosphere, suppressing local rainfall yet enhancing rainfall downwind when conditions for particle growth are more favourable (Andreae and Rosenfeld, 2008; Fan et al., 2018; Grandey and Wang, 2015; Lin et al., 2018; Guo et al., 2016). Changes to the source strength of ultra-fine and fine aerosols may therefore affect climate by either increasing or suppressing rainfall. The possibility of reduced precipitation is a critical question for rainfall-sensitive agriculture in NE Australia with ongoing degradation of the GBR and highlights the need for an improved understanding of the relationship between MBA emissions and their impact on cloud micro-physics.

\subsection{Other biogenic volatile organic compounds}

Although DMSP and its derivatives are the most abundant compounds in the coral-reef sulfur cycle $(\sim 95 \%$ of sulfur compounds), other VOCs such as isoprene, dimethyl disulfide (DMDS), carbon disulfide $\left(\mathrm{CS}_{2}\right)$ and the recently discovered DMSP variant, dimethylsulfoxonium propionate (DMSOP), are also produced in coral reefs (Swan et al., 2016;
Thume et al., 2018). Isoprene is the most abundant biogenic VOC in the atmosphere, largely derived from terrestrial vegetation; however, oceanic emissions are also reported from marine algae including Symbiodiniaceae (Exton et al., 2013). Swan et al. (2016) recorded large quantities of isoprene in A. aspera mucous, likely produced by expelled coral zooxanthellae. Isoprene may be oxidised in the atmosphere or condenses onto existing particles, thus also contributing to aerosol formation over coral reefs with the potential to affect local climate (Fan and Zhang, 2004; Kroll et al., 2006; Surratt et al., 2007). Photochemistry at the ocean surface is a sink of organic compounds, yet interfacial photochemical reactions also produce an important abiotic source of VOCs, estimated to be $23.2-91.9 \mathrm{Tg} \mathrm{C} \mathrm{yr}^{-1}$, contributing approximately $60 \%$ of organic aerosol mass in the remote MBL (Brüggemann et al., 2018).

\section{Outlook and the implications for coral bleaching}

The physiological response of corals to increasing light and/or temperature stress is nonlinear. As these environmental factors increase beyond optimal levels, DMS emissions initially increase, but when thermal and/or light stress becomes too great, DMS emissions from corals essentially shut down (Jones et al., 2007; Fischer and Jones, 2012). This means that there are fewer aerosol precursor compounds and potentially fewer secondary aerosols forming over the coral reef. Recent work examined anomalies in fine-mode AOD over the GBR during four mass coral bleaching events which occurred primarily due to marine heat waves (Jackson et al., 2018). Prior to each bleaching event, when SST was rising and corals were likely emitting more DMS, above-average AOD was observed. However, just prior to and during the bleaching events, when corals were likely experiencing physiological stress, AOD declined to normal background levels or below average levels where the coral reef was severely affected. Although these covarying events may be a coincidence, the synchronous decline in AOD with the onset of coral bleaching suggests a link between coral health and atmospheric properties in the GBR.

This raises some important and concerning questions. Will the nonlinear response of DMS emissions from coral reduce its ability to cope with future temperature rises? If coral reefs significantly affect local atmospheric conditions, what will the consequences of ongoing coral-reef degradation and coral bleaching be for local or regional climate? A decline in aerosol and LLC formation over relatively pristine coral reefs such as the GBR could occur, potentially increasing SST and establishing a positive feedback on coral stress.

\section{Future research}

Coral reefs are a significant source of dimethylated sulfur compounds; however, there remains substantial uncertainty 
surrounding the importance of DMS in coral homeostasis and local climate and the implications ongoing coral-reef degradation may have on these complex biogeophysical processes. It is important that future research monitors changes to coral health and community structure, the processes driving DMS biosynthesis and emissions, and characterises the properties of marine aerosols and LLC over coral reefs. Understanding these complex ecological and biogeophysical processes will require a multi-disciplinary approach, utilising field, laboratory and remotely sensed data in conjunction with Earth system models.

A key area for future research is the investigation of $\operatorname{DMS}(\mathrm{P})$ biosynthesis amongst different coral-reef taxa. The relative abundance of a range of VOCs has been investigated in some species which occupy coral reefs, including Acropora spp., Stylophora pistillata, Favites sp., Lobophytum sp. (soft coral), and cultured samples of benthic macroalgae and crustose coralline algae (Broadbent et al., 2002; Swan et al., 2016, 2017b). Further studies quantifying the biosynthesis of $\mathrm{DMS}(\mathrm{P})(\mathrm{O})$ in other coral genera and other DMS-producing life forms are needed. These studies should particularly focus on species which currently or are predicted to dominate disturbed coral-reef systems after an ecological regime shift, such as temperature-tolerant Scleractinian corals, soft corals (e.g. octocorals) and macroalgae. Further laboratory or mesocosm experiments must also investigate how $\operatorname{DMS}(\mathrm{P})(\mathrm{O})$ biosynthesis varies under multiple, synergistic stressors (e.g. Arnold et al., 2013) and whether a change in biosynthesis will assist corals in coping with future disturbances. For example, it is not known whether DMS emissions from thermo-tolerant coral species will increase with further ocean warming or whether ocean acidification and deteriorating water quality will impede coral resilience and result in a decline in emissions.

Long-term, high-frequency measurements of seawater and atmospheric DMS concentrations in coral reefs are also needed. Short-term field campaigns measuring $\mathrm{DMS}_{\mathrm{w}}$ and $\mathrm{DMS}_{\mathrm{a}}$ have been conducted over periods ranging from several days of consistent measurements to several months of sporadic measurements (e.g. Andreae et al., 1983; Jones et al., 2007, 2018; Swan et al., 2017a). These campaigns have been crucial in providing high-frequency, detailed data necessary to begin to understand the processes driving DMS emissions from coral reefs. For example, Swan et al. (2017a) identified spikes in $\mathrm{DMS}_{\mathrm{a}}$ emitted by corals at low tide at Heron Island during consistent $\mathrm{DMS}_{\mathrm{a}}$ sampling over a 2week period. Such periodic emissions may not have been captured without consistent measurements (every $\sim 15 \mathrm{~min}$ ) of local tide height and $\mathrm{DMS}_{\mathrm{a}}$ concentrations. This finding supported early indications that corals can be a much stronger, albeit intermittent, source of DMS during low tide, compared to the background oceanic signal, which is likely dominated by algal emissions (Andreae et al., 1983). However, field surveys are very cost- and resource-intensive (reviewed in Hedley et al., 2016). The establishment of an au- tonomous system (e.g. Dacey, 2010) would alleviate some of these caveats and greatly benefit this field of research. These data would allow diel and seasonal changes in DMS emissions from coral reefs to be investigated more thoroughly and allow long-term changes in emissions strength with ongoing climate change to be determined. However, field surveys alone cannot always capture the larger-scale processes involved in DMS oxidation, particle formation and growth. DMS has an atmospheric residence time of up to $1 \mathrm{~d}$ (Khan et al., 2016) and may therefore accumulate and affect aerosol and cloud properties over coral reefs downwind of the emissions source, where field sampling may not occur. Therefore, it can be difficult to deduce empirical relationships between local DMS emissions and atmospheric properties from field surveys alone.

Remote-sensing approaches are useful in this regard, as they enable rapid, cost- and time-efficient analysis of a wide range of variables at large temporal and spatial scales and can be directly compared with field observations. For example, long-term, high-frequency observations of finemode AOD are available from the Aerosol Robotic Network (AERONET) at Lucinda in the central GBR. Comparison of this dataset with long-term measurements of meteorological conditions and DMS $\mathrm{a}_{\mathrm{a}}$ above the adjacent coral reef would provide valuable insight into the role of DMS in local atmospheric properties. Furthermore, if empirical relationships between coral physiological stress and DMS(P) biosynthesis can be deduced from field and laboratory experiments, a remotely sensed proxy for sea surface DMS concentrations and sea-air flux from coral reefs can be calculated (e.g. Cropp et al., 2018; Jones et al., 2007, 2018), similar to that produced for phytoplankton (Galí et al., 2018). Such proxies could be used in conjunction with long-term data on coral cover and health (e.g. Australian Institute of Marine Science Long-term Monitoring Program) to estimate the source strength of DMS emissions over large regions such as the GBR under future climate scenarios.

Several remote-sensing approaches are currently used by coral-reef scientists and managers to monitor environmental conditions in coral reefs. The majority of these focus on SST and PAR anomalies, as these are largely considered to be the major stressors to corals and are often the dominant factors contributing to coral bleaching (Jones et al., 2002; Lesser, 2011). The National Oceanic and Atmospheric Administration (NOAA) Coral Reef Watch utilises satellitederived SST and PAR to produce several measures of coral thermal and light stress, including the Hotspot, Degree Heating Week (DHW) and Light Stress Damage (LSD) products (Liu et al., 2006; Skirving et al., 2018). For example, the DHW product is based on spatially dependent SST anomalies above the maximum climatological summertime SST. Empirical evidence has demonstrated that these remotely sensed products reliably predict the severity and extent of mass coral bleaching (Hughes et al., 2018; Bainbridge, 2017; Berkelmans, 2009; Liu et al., 2003; Skirving et al., 2018, 2019). 
These are also conditions which are known to affect coral DMS(P) biosynthesis. Investigating spatiotemporal trends in conditions that influence DMS(P) biosynthesis (e.g. thermal stress, measured as DHW), and atmospheric properties such as AOD, could provide insight into the role of DMS in local climate of coral reefs (e.g. Cropp et al., 2018; Jackson et al., 2018).

This information could then be used to inform regional Earth system models and to quantify the role of $\mathrm{DMS}_{\mathrm{a}}$ in the formation of sulfate aerosols, $\mathrm{CCN}$ and the properties of low-level marine clouds over coral reefs. Currently, DMS emissions from coral reefs are poorly constrained and are not explicitly included in any global DMS climatology. Some modelled studies show a weak relationship, or no relationship, between $\mathrm{DMS}_{\mathrm{a}}$ and atmospheric properties in the tropics, whereas strong relationships have been demonstrated in other ocean regions (e.g. Vallina et al., 2007). This may be due to low sensitivity of aerosol and CCN to DMS in the low latitudes or a consequence of poor representation of coralreef DMS emissions in global climatologies. Improving the representation of coral reefs in DMS databases, which are subsequently incorporated into Earth system models, would provide insight into the sensitivity of local climate to coralreef DMS emissions. Quantifying the radiative cooling effect of marine biogenic aerosols over coral reefs is increasingly important with ongoing ocean warming and coral bleaching.

\section{Mitigation strategies}

The predicted increase in the frequency and severity of mass coral bleaching events may require biological and/or physical interventional management strategies to conserve coral reefs. One possible method is the propagation of temperaturetolerant coral species throughout coral-reef ecosystems (Van Oppen et al., 2015). This may help degraded coral reefs recover from disturbances such as coral bleaching and help to prevent further mass coral bleaching events. As discussed above, our understanding of DMS(P) biosynthesis amongst coral taxa is relatively limited, and temperature tolerance does not always predict the rate of DMS emissions (Steinke et al., 2011). However, the propagation of these temperaturetolerant species may counteract the predicted decline in DMS emissions in coral reefs dominated by sensitive coral species with ongoing coral-reef degradation.

Other strategies are aimed at mitigating the warming effects of GHGs via physical means. Solar-radiation management (SRM) strategies essentially mimic natural marine aerosol emissions and involve injecting sea spray or sulfate particles into the atmosphere over coral reefs to increase the albedo of low-lying marine clouds (Crabbe, 2009; Irvine et al., 2017). In a modelled scenario, injecting $5 \mathrm{Tg} \mathrm{SO}_{2}$ annually into the stratosphere above Caribbean coral reefs reduced SST, irradiance and sea-level rise and resulted in a substantial decline in the number of mass coral bleaching events predicted to occur over the next 50 years (Zhang et al., 2017). Similarly, Kwiatkowski et al. (2015) reported that enhancing $\mathrm{SO}_{2}$ concentrations in the tropical stratosphere reduced SST and the risk of coral bleaching over the next 30 years under an RCP4.5 scenario (where GHG and aerosol emissions drive a $4.5 \mathrm{~W} \mathrm{~m}^{-2}$ increase in radiative forcing by 2100 ). Other studies have examined the effect of releasing sea spray from ocean-based vessels to the MBL over coral reefs to brighten low-level marine clouds. Latham et al. (2013) found that an enhanced source of sea-spray aerosol over the GBR, Caribbean and French Polynesia offset the warming effects associated with a doubling of atmospheric $\mathrm{CO}_{2}$, and this reduced the number of coral bleaching events predicted to occur until the end of this century. An additional benefit of these SRM strategies is the potential moderation of climate hazards (Irvine et al., 2019), such as the reduction in the severity of tropical cyclones with a decline in SST (Zhang et al., 2017; Latham et al., 2012).

Another approach involves the implementation of a biodegradable calcium carbonate surface film over coral reefs. Early trials conducted as part of the Surface Films to Attenuate Light into the Great Barrier Reef project have demonstrated that the film increased light attenuation by $30 \%$ and had no adverse effects on coral physiology (Great Barrier Reef Foundation, https://www.barrierreef. org/what-we-do/projects/sun-shield, last access: 10 January 2018). An initiative proposed by the Reef and Rainforest Research Centre and QLD tourism industry is investigating the feasibility of pumping deep, cold water from 10$30 \mathrm{~m}$ over coral reefs with high economic and environmental value. Early pilot studies are currently being conducted to test the feasibility of the technology at Moore Reef off the coast of Cairns (Reef and Rainforest Research Centre, unpublished data, 2017).

Solar geoengineering is a realistic approach which may provide short-term protection for high-value or vulnerable coral reefs from rising temperatures. Some of these approaches mimic marine biogenic aerosol emissions and may counteract a decline in DMS-derived sulfate emissions with ongoing coral-reef degradation. However, these approaches are highly cost- and resource-intensive, particularly for large coral-reef systems such as the GBR, and success would depend upon the willingness of governments and/or organisations to continue funding and implementing the technology. These strategies also do not address other coral-reef stressors such as ocean acidification, and the long-term implications are not yet completely understood (Crabbe, 2009; Irvine et al., 2017). Therefore, there is enormous incentive to improve our understanding of the natural drivers of coral resilience, including the role of DMS(P) in alleviating oxidative stress and influencing the radiative balance over coral reefs. Future research must decipher the role of DMS and other VOC emissions in marine aerosol and cloud formation. If DMS significantly influences aerosol and cloud properties and alleviates coral physiological stress, it is vital that we 
understand how these processes may be affected by ongoing anthropogenic and climate-change-related disturbances. Further research is also needed to understand the long-term implications of solar geoengineering strategies, which may need to be implemented as a last resort to conserve coral reefs.

\section{Conclusions}

There is substantial evidence that coral reefs are strong sources of dimethylated sulfur compounds. These play an important role in alleviating oxidative stress in the coral holobiont resulting from high temperatures, irradiance, aerial exposure and hyposalinity. It is possible that a side effect of this stress response provides a source of precursor compounds for the formation of secondary sulfate aerosols, with important implications for the radiative balance over coral reefs. There is strong seasonality in both DMS emissions and aerosol loading over the $2300 \mathrm{~km}$ stretch of relatively pristine coral reefs in the GBR - a relationship that is indicative of a substantial biogenic influence on AOD. Field studies have observed new particle formation events occurring over the GBR, and remote-sensing analyses have demonstrated that AOD is positively correlated with conditions that have been empirically shown to enhance coral DMS emissions. It is therefore possible that pristine coral reefs such as the GBR are a source of MBA, with important implications for coral resilience to future rises in ocean temperature.
Corals enhance DMS emissions in response to rising stress; however, emissions decline when coral physiological tolerance ranges are approached. The same trend has been observed for both AOD and LLC cover, which often coincide with coral bleaching events. Natural aerosols are an important source of $\mathrm{CCN}$, and cloud cover is a primary determinant of the spatial extent and severity of coral bleaching. Although the response of coral DMS emissions to the changing climate is uncertain, a decline in DMS-derived particles may exacerbate warming and the degradation of coral reefs. Capturing the complex biogeochemical and ocean-atmosphere interactions involved in the coral-reef sulfur cycle is a challenging task. A multi-disciplinary approach which utilises both field and remote-sensing observations, with Earth system models, is therefore needed to improve our understanding of the importance of DMS in coral physiology and climate. This will enable a better understanding of natural aerosol radiative effects and inform alternative methods of coral-reef management. 


\section{Appendix A: Glossary}

Aerosol

Aerosol optical depth (AOD)

Albedo

Catabolism

Cloud condensation nuclei $(\mathrm{CCN})$

Coral holobiont

Marine boundary layer (MBL)

Radiative forcing

Reactive oxygen species (ROSs)

Solar-radiation management (SRM)
Solid or liquid particle suspended in the atmosphere. Examples include sea spray, dust, smoke and biogenic sulfates.

Unitless measure of the amount of aerosol in the atmosphere, determined by the extinction of solar radiation.

The amount of solar radiation which is reflected from a surface, such as an aerosol particle or cloud droplet.

Metabolic pathway by which compounds are degraded into smaller units. In the coral holobiont, DMSP catabolism occurs via the demethylation (removal of a methyl group) or cleavage (enzymatic splitting of a chemical bond) pathways.

Aerosol particles on which water vapour condenses to form cloud droplets. CCN influence the lifetime, albedo and cover of clouds, with implications for precipitation and the Earth's radiative balance.

The coral host and all endosymbiotic micro-organisms, including microalgae, microbes and viruses.

The lower atmosphere in contact with the ocean surface, where the exchange of heat, moisture, momentum and chemical species between the ocean and atmosphere occurs. The net difference between top-of-atmosphere incoming and outgoing radiation due to interactions between solar radiation, aerosols, clouds and the Earth's surface (measured in $\mathrm{W} \mathrm{m}^{-2}$ ). Positive forcing indicates a warming effect, while negative forcing indicates a cooling effect.

Reactive oxygen produced by impaired algal photosystems and coral tissues during exposure to high temperatures and/or irradiance, which damage cells and tissues. Examples include the superoxide anion, hydroxyl radical and singlet oxygen.

A solar geoengineering approach to mitigating global warming via an increase in the aerosol and cloud albedo effect. 
Data availability. The aerosol optical depth dataset presented in this review can be obtained from NASA's OceanColor Distributed Active Archive Centre (https://doi.org/10.5067/AQUA/MODIS/L3M/IOP/2018 and https://doi.org/10.5067/TERRA/MODIS/L3M/IOP/2018 (NASA Goddard Space Flight Center et al., 2019).

Author contributions. RJ prepared the paper, with contributions from all co-authors.

Competing interests. The authors declare that they have no conflict of interest.

Acknowledgements. The authors gratefully acknowledge the MODIS mission scientists and NASA Ocean Biology Processing Group for the provision of aerosol optical depth data presented in this review. We also thank the NOAA Air Resources Laboratory (ARL) for the provision of the HYSPLIT transport and dispersion model and READY website (https://www.ready.noaa.gov, last access: 20 May 2019) used in this publication.

Financial support. Rebecca Jackson is supported by an Australian Government Research Training Program Scholarship, a Commonwealth Scientific and Industrial Research Organisation Scholarship, and the Griffith University School of Environment and Science.

Review statement. This paper was edited by S. Wajih A. Naqvi and reviewed by Michael Steinke and two anonymous referees.

\section{References}

Ainsworth, T. D., Heron, S. F., Ortiz, J. C., Mumby, P., Grech, A., Ogawa, D., Eakin, C. M., and Leggat, W.: Climate change disables coral bleaching protection on the Great Barrier Reef, Science, 352, 338-342, https://doi.org/10.1126/science.aac7125, 2016.

Albright, R., Takeshita, Y., Koweek, D. A., Ninokawa, A., Wolfe, K., Rivlin, T., Nebuchina, Y., Young, J., and Caldeira, K.: Carbon dioxide addition to coral reef waters suppresses net community calcification, Nature, 555, 516-519, https://doi.org/10.1038/nature25968, 2018.

Andreae, M. O. and Crutzen, P. J.: Atmospheric aerosols: Biogeochemical sources and role in atmospheric chemistry, Science, 276, 1052-1058, https://doi.org/10.1126/science.276.5315.1052, 1997.

Andreae, M. O. and Rosenfeld, D.: Aerosol-cloudprecipitation interactions. Part 1 . The nature and sources of cloud-active aerosols, Earth-Sci. Rev., 89, 13-41, https://doi.org/10.1016/j.earscirev.2008.03.001, 2008.

Andreae, M. O., Barnard, W., and Ammons, J.: The biological production of dimethylsulfide in the ocean and its role in the global atmospheric sulfur budget, Ecol. Bull., 35, 167-177, 1983.
Archer, S., Kimmance, S., Stephens, J., Hopkins, F., Bellerby, R., Schulz, K. G., Piontek, J., and Engel, A.: Contrasting responses of DMS and DMSP to ocean acidification in Arctic waters, Biogeosciences, 10, 1893-1908, https://doi.org/10.5194/bg-101893-2013, 2013.

Archer, S. D., Suffrian, K., Posman, K. M., Bach, L. T., Matrai, P. A., Countway, P. D., Ludwig, A., and Riebesell, U.: Processes that contribute to decreased dimethyl sulfide production in response to ocean acidification in subtropical waters, Front. Mar. Sci., 5, 245, https://doi.org/10.3389/fmars.2018.00245, 2018.

Arnold, H. E., Kerrison, P., and Steinke, M.: Interacting effects of ocean acidification and warming on growth and DMS-production in the haptophyte coccolithophore Emiliania huxleyi, Global Change Biol., 19, 1007-1016, https://doi.org/10.1111/gcb.12105, 2013.

Bainbridge, S. J.: Temperature and light patterns at four reefs along the Great Barrier Reef during the 20152016 austral summer: understanding patterns of observed coral bleaching, J. Operat. Oceanogr., 10, 16-29, https://doi.org/10.1080/1755876X.2017.1290863, 2017.

Baker, A. C., Glynn, P. W., and Riegl, B.: Climate change and coral reef bleaching: An ecological assessment of long-term impacts, recovery trends and future outlook, Estuarine, Coastal Shelf Sci., 80, 435-471, https://doi.org/10.1016/j.ecss.2008.09.003, 2008.

Barbier, E. B., Hacker, S. D., Kennedy, C., Koch, E. W., Stier, A. C., and Silliman, B. R.: The value of estuarine and coastal ecosystem services, Ecol. Monogr., 81, 169-193, https://doi.org/10.1890/10-1510.1, 2011.

Barnes, I., Hjorth, J., and Mihalopoulos, N.: Dimethyl sulfide and dimethyl sulfoxide and their oxidation in the atmosphere, Chem. Rev., 106, 940-975, https://doi.org/10.1021/cr020529+, 2006.

Bates, T., Lamb, B., Guenther, A., Dignon, J., and Stoiber, R.: Sulfur emissions to the atmosphere from natural sourees, J. Atmos. Chem., 14, 315-337, 1992.

Bay, L. K., Doyle, J., Logan, M., and Berkelmans, R.: Recovery from bleaching is mediated by threshold densities of background thermo-tolerant symbiont types in a reef-building coral, Roy. Soc. Open Sci., 3, 160322, https://doi.org/10.1098/rsos.160322, 2016.

Bell, P.: Eutrophication and coral reefs - some examples in the Great Barrier Reef lagoon, Water Res., 26, 553-568, 1992.

Berkelmans, R: Bleaching and mortality thresholds: how much is too much?, in: Coral Bleaching, edited by: van Oppen, M. J. and Lough, J. M., Springer, Berlin, Heidelberg, 103-119, 2009.

Berkelmans, R. and Van Oppen, M. J.: The role of zooxanthellae in the thermal tolerance of corals: a 'nugget of hope' for coral reefs in an era of climate change, P. Roy. Soc. B, 273, 2305-2312, https://doi.org/10.1098/rspb.2006.3567, 2006.

Bigg, E. and Turvey, D.: Sources of atmospheric particles over Australia, Atmos. Environ., 12, 1643-1655, 1978.

Bourne, D. G., Morrow, K. M., and Webster, N. S.: Insights into the coral microbiome: underpinning the health and resilience of reef ecosystems, Annu. Rev. Microbiol., 70, 317-340, https://doi.org/10.1146/annurev-micro-102215-095440, 2016.

Broadbent, A. D. and Jones, G. B.: DMS and DMSP in mucus ropes, coral mucus, surface films and sediment pore waters from coral reefs in the Great Barrier Reef, Mar. Freshwater Res., 55, 849855, https://doi.org/10.1071/MF04114, 2004. 
Broadbent, A. D. and Jones, G. B.: Seasonal and diurnal cycles of dimethylsulfide, dimethylsulfoniopropionate and dimethylsulfoxide at One Tree Reef lagoon, Environ. Chem., 3, 260-267, https://doi.org/10.1071/EN06011, 2006.

Broadbent, A. D., Jones, G. B., and Jones, R. J.: DMSP in corals and benthic algae from the Great Barrier Reef, Estuarine, Coast. Shelf Sci., 55, 547-555, https://doi.org/10.1006/ecss.2002.1021, 2002.

Brodie, J., Devlin, M., Haynes, D., and Waterhouse, J.: Assessment of the eutrophication status of the Great Barrier Reef lagoon (Australia), Biogeochemistry, 106, 281-302, https://doi.org/10.1007/s10533-010-9542-2, 2011.

Brown, K. T., Bender-Champ, D., Kenyon, T. M., Rémond, C., Hoegh-Guldberg, O., and Dove, S.: Temporal effects of ocean warming and acidification on coral-algal competition, Coral Reefs, 38, 297-309, https://doi.org/10.1007/s00338-019-01775y, 2019.

Brüggemann, M., Hayeck, N., and George, C.: Interfacial photochemistry at the ocean surface is a global source of organic vapors and aerosols, Nat. Commun., 9, 2101, https://doi.org/10.1038/s41467-018-04528-7, 2018.

Buckee, J., Pattiaratchi, C., and Verduin, J.: Partial mortality of intertidal corals due to seasonal daytime low water levels at the Houtman Abrolhos Islands, Coral Reefs, https://doi.org/10.1007/s00338-019-01887-5, in press, 2019.

Bullock, H. A., Luo, H., and Whitman, W. B.: Evolution of dimethylsulfoniopropionate metabolism in marine phytoplankton and bacteria, Front. Microbiol., 8, 637, https://doi.org/10.3389/fmicb.2017.00637, 2017.

Burdett, H. L., Hatton, A. D., and Kamenos, N. A.: Coralline algae as a globally significant pool of marine dimethylated sulfur, Global Biogeochem. Cy., 29, 1845-1853, https://doi.org/10.1002/2015GB005274, 2015.

Burke, L., Reytar, K., Spalding, M., and Perry, A.: Reefs at Risk Revisited, World Resources Institute, Washington, D.C., 2011.

Carslaw, K., Lee, L., Reddington, C., Pringle, K., Rap, A., Forster, P., Mann, G., Spracklen, D., Woodhouse, M., and Regayre, L.: Large contribution of natural aerosols to uncertainty in indirect forcing, Nature, 503, 67-71, https://doi.org/10.1038/nature12674, 2013.

Caruana, A. M. and Malin, G.: The variability in DMSP content and DMSP lyase activity in marine dinoflagellates, Prog. Oceanogr., 120, 410-424, https://doi.org/10.1016/j.pocean.2013.10.014, 2014.

Cesar, H., Burke, L., and Pet-Soede, L.: The economics of worldwide coral reef degradation, Cesar Environmental Economics Consulting (CEEC), the Netherlands, 2003.

Charlson, R. J., Lovelock, J. E., Andreae, M. O., and Warren, S. G.: Oceanic phytoplankton, atmospheric sulphur, cloud albedo and climate, Nature, 326, 655-661, 1987.

Chaves-Fonnegra, A., Riegl, B., Zea, S., Lopez, J. V., Smith, T., Brandt, M., and Gilliam, D. S.: Bleaching events regulate shifts from corals to excavating sponges in algaedominated reefs, Global Change Biol., 24, 773-785, https://doi.org/10.1111/gcb.13962, 2018.

Cooper, T. F., De'Ath, G., Fabricius, K. E., and Lough, J. M.: Declining coral calcification in massive Porites in two nearshore regions of the northern Great Barrier Reef, Global Change Biol.,
14, 529-538, https://doi.org/10.1111/j.1365-2486.2007.01520.x, 2008.

Costanza, R., de Groot, R., Sutton, P., Van der Ploeg, S., Anderson, S. J., Kubiszewski, I., Farber, S., and Turner, R. K.: Changes in the global value of ecosystem services, Global Environ. Change, 26, 152-158, https://doi.org/10.1016/j.gloenvcha.2014.04.002, 2014.

Crabbe, M. J. C.: Modelling effects of geoengineering options in response to climate change and global warming: Implications for coral reefs, Comput. Biol. Chem., 33, 415-420, https://doi.org/10.1016/j.compbiolchem.2009.09.004, 2009.

Cropp, R., Gabric, A., van Tran, D., Jones, G., Swan, H., and Butler, H.: Coral reef aerosol emissions in response to irradiance stress in the Great Barrier Reef, Australia, Ambio, 47, 671-681, https://doi.org/10.1007/s13280-018-1018-y, 2018.

Dacey, J. W.: Automated longterm measurement of atmospheric dimethylsulfide at Barrow, Alaska, Woods Hole Oceanographic Institute, Woods Hole, USA, 2010.

Dacey, J. W. and Wakeham, S. G.: Oceanic dimethylsulfide: production during zooplankton grazing on phytoplankton, Science, 233, 1314-1316, 1986

Dave, P., Patil, N., Bhushan, M., and Venkataraman, C.: Aerosol influences on cloud modification and rainfall suppression in the South Asian monsoon region, in: Climate Change Signals and Response, edited by: Venkataraman, C., Mishra, T., Ghosh, S., and Karmaker, S., Springer, Singapore, 21-37, 2019.

De'ath, G. and Fabricius, K.: Water quality as a regional driver of coral biodiversity and macroalgae on the Great Barrier Reef, Ecol. Appl., 20, 840-850, https://doi.org/10.1890/08-2023.1, 2010.

De'ath, G., Fabricius, K. E., Sweatman, H., and Puotinen, M.: The 27-year decline of coral cover on the Great Barrier Reef and its causes, P. Natl. Acad. Sci. USA, 109, 17995, https://doi.org/10.1073/pnas.1208909109, 2012.

Deschaseaux, E. S. M., Jones, G. B., Deseo, M. A., Shepherd, K. M., Kiene, R., Swan, H. B., Harrison, P. L., and Eyre, B. D.: Effects of environmental factors on dimethylated sulfur compounds and their potential role in the antioxidant system of the coral holobiont, Limnol. Oceanogr., 59, 758-768, https://doi.org/10.4319/lo.2014.59.3.0758, 2014a.

Deschaseaux, E. S. M., Beltran, V., Jones, G. B., Deseo, M. A., Swan, H. B., Harrison, P. L., and Eyre, B. D.: Comparative response of DMS and DMSP concentrations in Symbiodinium clades C1 and D1 under thermal stress, J. Exp. Mar. Biol. Ecol., 459, 181-189, https://doi.org/10.1016/j.jembe.2014.05.018, 2014b.

Diaz, R. J. and Rosenberg, R.: Spreading dead zones and consequences for marine ecosystems, Science, 321, 926-929, https://doi.org/10.1126/science.1156401, 2008.

Downs, C. A., Fauth, J. E., Halas, J. C., Dustan, P., Bemiss, J., and Woodley, C. M.: Oxidative stress and seasonal coral bleaching, Free Radic. Biol. Med., 33, 533-543, https://doi.org/10.1016/S0891-5849(02)00907-3, 2002.

Dubinsky, Z. and Falkowski, P.: Light as a source of information and energy in zooxanthellate corals, in: Coral Reefs: An Ecosystem in Transition, edited by: Dubinski, Z. and Stambler, N., Springer, Dordrecht, 107-118, 2011.

Erftemeijer, P. L., Riegl, B., Hoeksema, B. W., and Todd, P. A.: Environmental impacts of dredging and other sediment distur- 
bances on corals: a review, Mar. Pollut. Bull., 64, 1737-1765, https://doi.org/10.1016/j.marpolbul.2012.05.008, 2012.

Exton, D., Suggett, D., McGenity, T., and Steinke, M.: Chlorophyll-normalized isoprene production in laboratory cultures of marine microalgae and implications for global models, Limnol. Oceanogr., 58, 1301-1311, https://doi.org/10.4319/1o.2013.58.4.1301, 2013.

Fabricius, K., Okaji, K., and De'Ath, G.: Three lines of evidence to link outbreaks of the crown-of-thorns seastar Acanthaster planci to the release of larval food limitation, Coral Reefs, 29, 593-605, https://doi.org/10.1007/s00338-010-0628-z, 2010.

Falkowski, P. G., Dubinsky, Z., Muscatine, L., and Porter, J. W.: Light and the bioenergetics of a symbiotic coral, Bioscience, 34 , 705-709, 1984.

Fan, J. and Zhang, R.: Atmospheric oxidation mechanism of isoprene, Environ. Chem., 1, 140-149, https://doi.org/10.1071/EN04045, 2004.

Fan, J., Rosenfeld, D., Zhang, Y., Giangrande, S. E., Li, Z., Machado, L. A., Martin, S. T., Yang, Y., Wang, J., and Artaxo, P.: Substantial convection and precipitation enhancements by ultrafine aerosol particles, Science, 359, 411-418, https://doi.org/10.1126/science.aan8461, 2018.

Ferrario, F., Beck, M. W., Storlazzi, C. D., Micheli, F., Shepard, C. C., and Airoldi, L.: The effectiveness of coral reefs for coastal hazard risk reduction and adaptation, Nat. Commun., 5, 3794, https://doi.org/10.1038/ncomms4794, 2014.

Fiddes, S. L., Woodhouse, M. T., Nicholls, Z., Lane, T. P., and Schofield, R.: Cloud, precipitation and radiation responses to large perturbations in global dimethyl sulfide, Atmos. Chem. Phys., 18, 10177-10198, https://doi.org/10.5194/acp-18-101772018, 2018.

Fischer, E. and Jones, G.: Atmospheric dimethysulphide production from corals in the Great Barrier Reef and links to solar radiation, climate and coral bleaching, Biogeochemistry, 110, 31-46, https://doi.org/10.1007/s10533-012-9719-y, 2012.

Frade, P., Schwaninger, V., Glasl, B., Sintes, E., Hill, R., Simó, R., and Herndl, G.: Dimethylsulfoniopropionate in corals and its interrelations with bacterial assemblages in coral surface mucus, Environ. Chem., 13, 252-265, 2016.

Gabric, A. J., Matrai, P., Jones, G. B., and Middleton, J.: The nexus between sea ice and polar emissions of marine biogenic aerosols, B. Am. Meteorol. Soc., 99, 61-82, https://doi.org/10.1175/BAMS-D-16-0254.1, 2018.

Gabric, A. J., Qu, B., Matrai, P., and Hirst, A. C.: The simulated response of dimethylsulfide production in the Arctic Ocean to global warming, Tellus B, 57, 391-403, https://doi.org/10.3402/tellusb.v57i5.16564, 2005.

Gabric, A. J., Qu, B., Rotstayn, L., and Shephard, J. M.: Global simulations of the impact on contemporary climate of a perturbation to the sea-to-air flux of dimethylsulfide, Aust. Meteorol. Oceanogr. J., 63, 365-376, 2013.

Gage, D. A., Rhodes, D., Nolte, K. D., Hicks, W. A., Leustek, T., Cooper, A. J., and Hanson, A. D.: A new route for synthesis of dimethylsulphoniopropionate in marine algae, Nature, 387, 891894, 1997.

Galí, M., Levasseur, M., Devred, E., Simó, R., and Babin, M.: Seasurface dimethylsulfide (DMS) concentration from satellite data at global and regional scales, Biogeosciences, 15, 3497-3519, https://doi.org/10.5194/bg-15-3497-2018, 2018.
Gardner, S. G., Nielsen, D. A., Laczka, O., Shimmon, R., Beltran, V. H., Ralph, P. J., and Petrou, K.: Dimethylsulfoniopropionate, superoxide dismutase and glutathione as stress response indicators in three corals under short-term hyposalinity stress, P. Roy. Soc. B, 283, 20152418, https://doi.org/10.1098/rspb.2015.2418, 2016.

Gates, R. D., Baghdasarian, G., and Muscatine, L.: Temperature stress causes host cell detachment in symbiotic cnidarians: implications for coral bleaching, Biolog. Bull., 182, 324-332, 1992.

Gattuso, J. P., Frankignoulle, M., and Wollast, R.: Carbon and carbonate metabolism in coastal aquatic ecosystems, Annu. Rev. Ecol. System., 29, 405-434, 1998.

Grandey, B. S. and Wang, C.: Enhanced marine sulphur emissions offset global warming and impact rainfall, Scient. Rep., 5, 13055, https://doi.org/10.1038/srep13055, 2015.

Green, T., Hatton, A. D., Hughes, R. N., Hughes, D. J., and Smith, I. P.: The CLAW hypothesis: a new perspective on the role of biogenic sulphur in the regulation of global climate, Oceanogr. Mar. Biol.: Annu. Rev., 52, 315-336, 2014.

Guo, L., Turner, A. G., and Highwood, E. J.: Local and remote impacts of aerosol species on Indian summer monsoon rainfall in a GCM, J. Climate, 29, 6937-6955, https://doi.org/10.1175/JCLID-15-0728.1, 2016.

Haydon, T. D., Seymour, J. R., and Suggett, D. J.: Soft corals are significant DMSP producers in tropical and temperate reefs, Mar. Biol., 165, 109, https://doi.org/10.1007/s00227-018-33672, 2018

Hedley, J., Roelfsema, C., Chollett, I., Harborne, A., Heron, S., Weeks, S., Skirving, W., Strong, A., Eakin, C., and Christensen, T.: Remote sensing of coral reefs for monitoring and management: a review, Remote Sensing, 8, 118, 2016.

Heron, S. F., Maynard, J. A., Van Hooidonk, R., and Eakin, C. M.: Warming trends and bleaching stress of the world's coral reefs 1985-2012, Scient. Rep., 6, 38402, https://doi.org/10.1038/srep38402, 2016.

Hill, R. W., Dacey, J. W., and Krupp, D. A.: Dimethylsulfoniopropionate in reef corals, Bull. Mar. Sci., 57, 489-494, 1995.

Hill, R. W., Dacey, J., and Edward, A.: Dimethylsulfoniopropionate in giant clams (Tridacnidae), Biolog. Bull., 199, 108-115, https://doi.org/10.2307/1542870, 2000.

Hill, R. W, Li, C., Jones, A., Gunn, J., and Frade, P.: Abundant betaines in reef-building corals and ecological indicators of a photoprotective role, Coral Reefs, 29, 869-880, https://doi.org/10.1007/s00338-010-0662-x, 2010.

Ho, D. T. and Wanninkhof, R.: Air-sea gas exchange in the North Atlantic: ${ }^{3} \mathrm{He} / \mathrm{SF}_{6}$ Experiment during GasEx-98, Tellus B, 68, 30198, https://doi.org/10.3402/tellusb.v68.30198, 2016.

Hoegh-Guldberg, O., Mumby, P. J., Hooten, A. J., Steneck, R. S., Greenfield, P., Gomez, E., Harvell, C. D., Sale, P. F., Edwards, A. J., and Caldeira, K.: Coral reefs under rapid climate change and ocean acidification, Science, 318, 1737-1742, https://doi.org/10.1126/science.1152509, 2007.

Hoffmann, E. H., Tilgner, A., Schrödner, R., Bräuer, P., Wolke, R., and Herrmann, H.: An advanced modeling study on the impacts and atmospheric implications of multiphase dimethyl sulfide chemistry, P. Natl. Acad. Sci. USA, 113, 11776-11781, https://doi.org/10.1073/pnas.1606320113, 2016.

Hopkins, F. E., Bell, T. G., Yang, M., Suggett, D. J., and Steinke, M.: Air exposure of coral is a significant source of dimethyl- 
sulfide (DMS) to the atmosphere, Scient. Rep., 6, 36031, https://doi.org/10.1038/srep36031, 2016.

Hopkins, F. E., Nightingale, P. D., Stephens, J. A., Moore, C. M., Richier, S., Cripps, G. L., and Archer, S. D.: A meta-analysis of microcosm experiments shows that dimethyl sulfide (DMS) production in polar waters is insensitive to ocean acidification, Biogeosciences, 17, 163-186, https://doi.org/10.5194/bg17-163-2020, 2020.

Howarth, R., Chan, F., Conley, D. J., Garnier, J., Doney, S. C., Marino, R., and Billen, G.: Coupled biogeochemical cycles: eutrophication and hypoxia in temperate estuaries and coastal marine ecosystems, Front. Ecol. Environ., 9, 18-26, https://doi.org/10.1890/100008, 2011.

Hughes, T. P., Kerry, J. T., Baird, A. H., Connolly, S. R., Dietzel, A., Eakin, C. M., Heron, S. F., Hoey, A. S., Hoogenboom, M. O., and Liu, G.: Global warming transforms coral reef assemblages, Nature, 556, 492-496, https://doi.org/10.1038/s41586-018-0041-2, 2018.

Hughes, T. P., Kerry, J. T., Baird, A. H., Connolly, S. R., Chase, T. J., Dietzel, A., Hill, T., Hoey, A. S., Hoogenboom, M. O., Jacobson, M., Kerswell, A., Madin, J. S., Mieog, A., Paley, A. S., Pratchett, M. S., Torda, G., and Woods, R. M.: Global warming impairs stock recruitment dynamics of corals, Nature, 568, 387390, https://doi.org/10.1038/s41586-019-1081-y, 2019.

Inoue, S., Kayanne, H., Yamamoto, S., and Kurihara, H.: Spatial community shift from hard to soft corals in acidified water, Nat. Clim. Change, 3, 683-687, https://doi.org/10.1038/NCLIMATE1855, 2013.

IPCC: Climate change 2014: Synthesis report, in: Contribution of Working Groups I, II and III to the Fifth Assessment Report of the Intergovernmental Panel on Climate Change, edited by: Core writing team, Pachauri, R. K., and Meyer, L. A., IPCC, Geneva, Switzerland, 2014.

Irvine, P. J., Kravitz, B., Lawrence, M. G., Gerten, D., Caminade, C., Gosling, S. N., Hendy, E. J., Kassie, B. T., Kissling, W. D., and Muri, H.: Towards a comprehensive climate impacts assessment of solar geoengineering, Earth's Future, 5, 93-106, https://doi.org/10.1002/2016EF000389, 2017.

Irvine, P. J., Emanuel, K., He, J., Horowitz, L. W., Vecchi, G., and Keith, D.: Halving warming with idealized solar geoengineering moderates key climate hazards, Nat. Clim. Change, 9, 295-299, https://doi.org/10.1038/s41558-019-0398-8, 2019.

Jackson, R., Gabric, A., and Cropp, R.: Effects of ocean warming and coral bleaching on aerosol emissions in the Great Barrier Reef, Australia, Scient. Rep., 8, 14048, https://doi.org/10.1038/s41598-018-32470-7, 2018.

Jones, G. B.: The Reef Sulphur Cycle: Influence on Climate and Ecosystem Services, in: Ethnobiology of Corals and Coral Reefs, Springer, Cham, 27-57, 2015.

Jones, G. B. and Trevena, A. J.: The influence of coral reefs on atmospheric dimethylsulphide over the Great Barrier Reef, Coral Sea, Gulf of Papua and Solomon and Bismarck Seas, Mar. Freshwater Res., 56, 85-93, https://doi.org/10.1071/MF04097, 2005.

Jones, G. B., Curran, M., Broadbent, A., King, S., Fischer, E., and Jones, R.: Factors affecting the cycling of dimethylsulfide and dimethylsulfoniopropionate in coral reef waters of the Great Barrier Reef, Environ. Chem., 4, 310-322, https://doi.org/10.1071/EN06065, 2007.
Jones, G. B., Fischer, E., Deschaseaux, E. S., and Harrison, P. L.: The effect of coral bleaching on the cellular concentration of dimethylsulphoniopropionate in reef corals, J. Exp. Mar. Biol. Ecol., 460, 19-31, https://doi.org/10.1016/j.jembe.2014.06.003, 2014.

Jones, G. B., Curran, M., Swan, H. B., and Deschaseaux, E. S. M.: Dimethylsulfide and coral bleaching: Links to solar radiation, low level cloud and the regulation of seawater temperatures and climate in the Great Barrier Reef, Am. J. Clim. Change, 6, 328-359, https://doi.org/10.4236/ajcc.2017.62017, 2017.

Jones, G. B., Curran, M., Deschaseaux, E. S. M., Omori, Y., Tanimoto, H., Swan, H. B., Eyre, B., Ivey, J., McParland, E., and Gabric, A.: The flux and emission of dimethylsulfide from the Great Barrier Reef region and potential influence on the climate of NE Australia, J. Geophys. Res.-Atmos., 123, 13835-13856, https://doi.org/10.1029/2018JD029210, 2018.

Jones, R. J., Berkelmans, R., and Oliver, J. K.: Recurrent bleaching of corals at Magnetic Island (Australia) relative to air and seawater temperature, Mar. Ecol. Prog. Ser., 158, 289-292, https://doi.org/10.3354/meps158289, 1997.

Jones, R. J., Hoegh-Guldberg, O., Larkum, A. W., and Schreiber, U.: Temperature-induced bleaching of corals begins with impairment of the $\mathrm{CO}_{2}$ fixation mechanism in zooxanthellae, Plant Cell Environ., 21, 1219-1230, https://doi.org/10.1046/j.13653040.1998.00345.x, 2002.

Kettle, A. and Andreae, M.: Flux of dimethylsulfide from the oceans: A comparison of updated data sets and flux models, J. Geophys. Res.-Atmos., 105, 26793-26808, https://doi.org/10.1029/2000JD900252, 2000.

Khan, M., Gillespie, S., Razis, B., Xiao, P., Davies-Coleman, M., Percival, C., Derwent, R., Dyke, J., Ghosh, M., and Lee, E.: A modelling study of the atmospheric chemistry of DMS using the global model, STOCHEM-CRI, Atmos. Environ., 127, 69-79, https://doi.org/10.1016/j.atmosenv.2015.12.028, 2016.

Kleypas, J. A., Danabasoglu, G., and Lough, J. M.: Potential role of the ocean thermostat in determining regional differences in coral reef bleaching events, Geophys. Res. Lett., 35, L03613, https://doi.org/10.1029/2007GL032257, 2008.

Kloster, S., Six, K., Feichter, J., Maier-Reimer, E., Roeckner, E., Wetzel, P., Stier, P., and Esch, M.: Response of dimethylsulfide (DMS) in the ocean and atmosphere to global warming, J. Geophys. Res.-Biogeo., 112, G03005, https://doi.org/10.1029/2006JG000224, 2007.

Klueter, A., Trapani, J., Archer, F. I., McIlroy, S. E., and Coffroth, M. A.: Comparative growth rates of cultured marine dinoflagellates in the genus Symbiodinium and the effects of temperature and light, PLOS One, 12, e0187707, https://doi.org/10.1371/journal.pone.0187707, 2017.

Korhonen, H., Carslaw, K. S., Spracklen, D. V., Mann, G. W., and Woodhouse, M. T.: Influence of oceanic dimethyl sulfide emissions on cloud condensation nuclei concentrations and seasonality over the remote Southern Hemisphere oceans: A global model study, J. Geophys. Res.-Atmos., 113, D15204, https://doi.org/10.1029/2007JD009718, 2008.

Kroll, J. H., Ng, N. L., Murphy, S. M., Flagan, R. C., and Seinfeld, J. H.: Secondary organic aerosol formation from isoprene photooxidation, Environ. Sci. Technol., 40, 1869-1877, https://doi.org/10.1021/es0524301, 2006. 
Kumar, P.: The economics of medicinal plants: Are high commerical values enough to ensure biodiversity conservation?, in: Conserving medicinal species: Securing a healthy future, edited by: Miththapala, S., IUCN - Ecosystems and Livelihoods Group, Asia, 9-15, 2006.

Kwiatkowski, L., Cox, P., Halloran, P. R., Mumby, P. J., and Wiltshire, A. J.: Coral bleaching under unconventional scenarios of climate warming and ocean acidification, Nat. Clim. Change, 5, 777-781, https://doi.org/10.1038/NCLIMATE2655, 2015.

LaJeunesse, T. C., Parkinson, J. E., Gabrielson, P. W., Jeong, H. J., Reimer, J. D., Voolstra, C. R., and Santos, S. R.: Systematic revision of Symbiodiniaceae highlights the antiquity and diversity of coral endosymbionts, Curr. Biol., 28, 2570-2580, https://doi.org/10.1016/j.cub.2018.07.008, 2018.

Lana, A., Bell, T., Simó, R., Vallina, S., Ballabrera-Poy, J., Kettle, A., Dachs, J., Bopp, L., Saltzman, E., and Stefels, J.: An updated climatology of surface dimethlysulfide concentrations and emission fluxes in the global ocean, Global Biogeochem. Cy., 25, GB1004, https://doi.org/10.1029/2010GB003850, 2011.

Lana, A., Simó, R., Vallina, S., and Dachs, J.: Potential for a biogenic influence on cloud microphysics over the ocean: A correlation study with satellite-derived data, Atmos. Chem. Phys., 12, 7977-7993, https://doi.org/10.5194/acp-12-7977-2012, 2012.

Land, P. E., Shutler, J. D., Bell, T., and Yang, M.: Exploiting satellite earth observation to quantify current global oceanic DMS flux and its future climate sensitivity, J. Geophys. Res.-Oceans, 119, 7725-7740, https://doi.org/10.1002/2014JC010104, 2014.

Latham, J., Parkes, B., Gadian, A., and Salter, S.: Weakening of hurricanes via marine cloud brightening (MCB), Atmos. Sci. Lett., 13, 231-237, https://doi.org/10.1002/asl.402, 2012.

Latham, J., Kleypas, J., Hauser, R., Parkes, B., and Gadian, A.: Can marine cloud brightening reduce coral bleaching?, Atmos. Sci. Lett., 14, 214-219, https://doi.org/10.1002/asl2.442, 2013.

Leahy, S. M., Kingsford, M. J., and Steinberg, C. R.: Do clouds save the Great Barrier Reef? Satellite imagery elucidates the cloud-SST relationship at the local scale, PLOS One, 8, e70400, https://doi.org/10.1371/journal.pone.0070400, 2013.

Leck, C. and Bigg, E. K.: Comparison of sources and nature of the tropical aerosol with the summer high Arctic aerosol, Tellus B, 60, 118-126, https://doi.org/10.1111/j.1600-0889.2007.00315.x, 2008.

Le Quéré, C., Andrew, R. M., Friedlingstein, P., Sitch, S., Hauck, J., Pongratz, J., Pickers, P. A., Korsbakken, J. I., Peters, G. P., Canadell, J. G., Arneth, A., Arora, V. K., Barbero, L., Bastos, A., Bopp, L., Chevallier, F., Chini, L. P., Ciais, P., Doney, S. C., Gkritzalis, T., Goll, D. S., Harris, I., Haverd, V., Hoffman, F. M., Hoppema, M., Houghton, R. A., Hurtt, G., Ilyina, T., Jain, A. K., Johannessen, T., Jones, C. D., Kato, E., Keeling, R. F., Goldewijk, K. K., Landschützer, P., Lefèvre, N., Lienert, S., Liu, Z., Lombardozzi, D., Metzl, N., Munro, D. R., Nabel, J. E. M. S., Nakaoka, S., Neill, C., Olsen, A., Ono, T., Patra, P., Peregon, A., Peters, W., Peylin, P., Pfeil, B., Pierrot, D., Poulter, B., Rehder, G., Resplandy, L., Robertson, E., Rocher, M., Rödenbeck, C., Schuster, U., Schwinger, J., Séférian, R., Skjelvan, I., Steinhoff, T., Sutton, A., Tans, P. P., Tian, H., Tilbrook, B., Tubiello, F. N., van der Laan-Luijkx, I. T., van der Werf, G. R., Viovy, N., Walker, A. P., Wiltshire, A. J., Wright, R., Zaehle, S., and Zheng, B.: Global Carbon Budget 2018, Earth Syst. Sci. Data, 10, 21412194, https://doi.org/10.5194/essd-10-2141-2018, 2018.
Lesser, M. P.: Oxidative stress in marine environments: biochemistry and physiological ecology, Annu. Rev. Physiol., 68, 253278, https://doi.org/10.1146/annurev.physiol.68.040104.110001, 2006.

Lesser, M. P.: Coral bleaching: causes and mechanisms, in: Coral Reefs: An Ecosystem in Transition, edited by: Dubinksy, Z. and Stambler, N., Springer, Dordrecht, 405-419, 2011.

Lesser, M. P., Stochaj, W., Tapley, D., and Shick, J.: Bleaching in coral reef anthozoans: effects of irradiance, ultraviolet radiation, and temperature on the activities of protective enzymes against active oxygen, Coral Reefs, 8, 225-232, 1990.

Lesser, M. P., Mazel, C., Gorbunov, M., and Falkowski, P.: Discovery of symbiotic nitrogen-fixing cyanobacteria in corals, Science, 305, 997-1000, https://doi.org/10.1126/science.1099128, 2004.

Lin, H., Kuzminov, F. I., Park, J., Lee, S., Falkowski, P. G., and Gorbunov, M. Y.: The fate of photons absorbed by phytoplankton in the global ocean, Science, 351, 264-267, https://doi.org/10.1126/science.aab2213, 2016.

Lin, L., Wang, Z., Xu, Y., Fu, Q., and Dong, W.: Larger sensitivity of precipitation extremes to aerosol than greenhouse gas forcing in CMIP5 models, J. Geophys. Res.-Atmos., 123, 8062-8073, https://doi.org/10.1029/2018JD028821, 2018.

Liu, G., Strong, A. E., and Skirving, W.: Remote sensing of sea surface temperatures during 2002 Barrier Reef coral bleaching, Eos Trans. Am. Geophys. Union, 84, 137-141, https://doi.org/10.1029/2003EO150001, 2003.

Liu, G., Strong, A. E., Skirving, W., and Arzayus, L. F.: Overview of NOAA coral reef watch program's near-real time satellite global coral bleaching monitoring activities, in: Proceedings of the 10th International Coral Reef Symposium, 28 June-2 July 2006, Okinawa, Japan, 1783-1793, 2006.

Lough, J.: Shifting climate zones for Australia's tropical marine ecosystems, Geophys. Res. Lett., 35, L14708, https://doi.org/10.1029/2008GL034634, 2008.

MacNeil, M. A., Mellin, C., Matthews, S., Wolff, N. H., McClanahan, T. R., Devlin, M., Drovandi, C., Mengersen, K., and Graham, N. A. J.: Water quality mediates resilience on the Great Barrier Reef, Nat. Ecol. Evol., 3, 620-627, https://doi.org/10.1038/s41559-019-0832-3, 2019.

McClanahan, T. R., Graham, N. A., MacNeil, M. A., Muthiga, N. A., Cinner, J. E., Bruggemann, J. H., and Wilson, S. K.: Critical thresholds and tangible targets for ecosystem-based management of coral reef fisheries, P. Natl. Acad. Sci. USA, 108, 1723017233, https://doi.org/10.1073/pnas.1106861108, 2011.

McCook, L. J. and Diaz-Pulido, G.: The fate of bleached corals: patterns and dynamics of algal recruitment, Mar. Ecol. Prog. Ser., 232, 115-128, https://doi.org/10.3354/meps232115, 2002.

McCoy, D. T., Burrows, S. M., Wood, R., Grosvenor, D. P., Elliott, S. M., Ma, P.-L., Rasch, P. J., and Hartmann, D. L.: Natural aerosols explain seasonal and spatial patterns of Southern Ocean cloud albedo, Sci. Adv., 1, e1500157, https://doi.org/10.1126/sciadv.1500157, 2015.

McEwan, J., Gabric, A. J., and Bell, P. R.: Water quality and phytoplankton dynamics in Moreton Bay, south-eastern Queensland. I. Field survey and satellite data, Mar. Freshwater Res., 49, 215 225, 1998.

McKergow, L. A., Prosser, I. P., Hughes, A. O., and Brodie, J.: Sources of sediment to the Great Barrier 
Reef world heritage area, Mar. Pollut. Bull., 51, 200-211, https://doi.org/10.1016/j.marpolbul.2004.11.029, 2005.

Mellin, C., Matthews, S., Anthony, K. R. N., Brown, S. C., Caley, M. J., Johns, K., Osborne, K., Puotinen, M., Thompson, A., Wolff, N. H., Fordham, D. A., and MacNeil, M. A.: Spatial resilience of the Great Barrier Reef under cumulative disturbance impacts, Global Change Biol., https://doi.org/10.1111/gcb.14625, in press, 2019.

Modini, R. L., Ristovski, Z., Johnson, G. R., He, C., Surawski, N., Morawska, L., Suni, T., and Kulmala, M.: New particle formation and growth at a remote, sub-tropical coastal location, Atmos. Chem. Phys., 9, 7607-7621, https://doi.org/10.5194/acp-9-76072009, 2009.

Mulcahy, J., Jones, C., Sellar, A., Johnson, B., Boutle, I., Jones, A., Andrews, T., Rumbold, S., Mollard, J., and Bellouin, N.: Improved aerosol processes and effective radiative forcing in HadGEM3 and UKESM1, J. Adv. Model. Earth Syst., 10, 27862805, https://doi.org/10.1029/2018MS001464, 2018.

Mumby, P. J., Chisholm, J., Edwards, A., Clark, C., Roark, E., Andrefouet, S., and Jaubert, J.: Unprecedented bleaching-induced mortality in Porites spp. at Rangiroa Atoll, French Polynesia, Mar. Biol., 139, 183-189, https://doi.org/10.1007/s002270100575, 2001a.

Mumby, P. J., Chisholm, J. R., Edwards, A. J., Andrefouet, S., and Jaubert, J.: Cloudy weather may have saved Society Island reef corals during the 1998 ENSO event, Mar. Ecol. Prog. Ser., 222, 209-216, https://doi.org/10.3354/meps222209, 2001b.

Muscatine, L. and Porter, J. W.: Reef corals: mutualistic symbioses adapted to nutrient-poor environments, Bioscience, 27, 454-460, 1977.

NASA Goddard Space Flight Center, Ocean Ecology Laboratory, and Ocean Biology Processing Group: Moderate Resolution Imaging Spectroradiometer (MODIS) Aqua and Terra Aerosol Optical Depth Data, NASA OB.DAAC, Greenbelt, MD, USA, https://doi.org/10.5067/AQUA/MODIS/L3M/IOP/2018 and https://doi.org/10.5067/TERRA/MODIS/L3M/IOP/2018, 2019.

Nielsen, D. A., Petrou, K., and Gates, R. D.: Coral bleaching from a single cell perspective, ISME J., 12, 1558, https://doi.org/10.1038/s41396-018-0080-6, 2018.

Norström, A. B., Nyström, M., Lokrantz, J., and Folke, C.: Alternative states on coral reefs: beyond coral-macroalgal phase shifts, Mar. Ecol. Prog. Ser., 376, 295-306, https://doi.org/10.3354/meps07815, 2009.

Orr, J. C.: Recent and future changes in ocean carbonate chemistry, Ocean Acidificat., 1, 41-66, 2011.

Osborne, N. J., Webb, P. M., and Shaw, G. R.: The toxins of Lyngbya majuscula and their human and ecological health effects, Environ. Int., 27, 381-392, https://doi.org/10.1016/S01604120(01)00098-8, 2001.

Qu, B., Gabric, A. J., Zeng, M., Xi, J., Jiang, L., and Zhao, L.: Dimethylsulfide model calibration and parametric sensitivity analysis for the Greenland Sea, Polar Sci., 13, 13-22, https://doi.org/10.1016/j.polar.2017.07.001, 2017.

Quinn, P. and Bates, T.: The case against climate regulation via oceanic phytoplankton sulphur emissions, Nature, 480, 51-56, https://doi.org/10.1038/nature10580, 2011.

Raina, J.-B., Tapiolas, D., Willis, B. L., and Bourne, D. G.: Coral-associated bacteria and their role in the biogeochemical cycling of sulfur, Appl. Environ. Microbiol., 75, 3492-3501, https://doi.org/10.1128/AEM.02567-08, 2009.

Raina, J.-B., Dinsdale, E. A., Willis, B. L., and Bourne, D. G.: Do the organic sulfur compounds DMSP and DMS drive coral microbial associations?, Trends Microbiol., 18, 101-108, https://doi.org/10.1016/j.tim.2009.12.002, 2010.

Raina, J.-B., Tapiolas, D. M., Forêt, S., Lutz, A., Abrego, D., Ceh, J., Seneca, F. O., Clode, P. L., Bourne, D. G., and Willis, B. L.: DMSP biosynthesis by an animal and its role in coral thermal stress response, Nature, 502, 677-680, https://doi.org/10.1038/nature12677, 2013.

Raina, J.-B., Tapiolas, D., Motti, C. A., Foret, S., Seemann, T., Tebben, J., Willis, B. L., and Bourne, D. G.: Isolation of an antimicrobial compound produced by bacteria associated with reef-building corals, Peer J., 4, e2275, https://doi.org/10.7717/peerj.2275, 2016.

Ramanathan, V. and Collins, W.: Thermodynamic regulation of ocean warming by cirrus clouds deduced from observations of the 1987 El Nino, Nature, 351, 27-32, https://doi.org/10.1038/351027a0, 1991.

Reaka-Kudla, M.: Global biodiversity of coral reefs: a comparison with rainforests, in: Biodiversity II: Understanding and protecting our biological resources, edited by: Reaka-Kudla, M., Wilson, D., Wilson, E., and Peter, F., Joseph Henry Press, Washington, USA, 83-108, 1997.

Rolph, G., Stein, A., and Stunder, B.: Real-time Environmental Applications and Display sYstem: READY, Environ. Model. Softw., 95, 210-228, https://doi.org/10.1016/j.envsoft.2017.06.025, 2017.

Rosenfeld, D., Dai, J., Yu, X., Yao, Z., Xu, X., Yang, X., and $\mathrm{Du}, \mathrm{C} .:$ Inverse relations between amounts of air pollution and orographic precipitation, Science, 315, 1396-1398, https://doi.org/10.1126/science.1137949, 2007.

Sanchez, K. J., Chen, C.-L., Russell, L. M., Betha, R., Liu, J., Price, D. J., Massoli, P., Ziemba, L. D., Crosbie, E. C., and Moore, R H.: Substantial seasonal contribution of observed biogenic sulfate particles to cloud condensation nuclei, Scient. Rep., 8, 3235, https://doi.org/10.1038/s41598-018-21590-9, 2018.

Schwinger, J., Tjiputra, J., Goris, N., Six, K. D., Kirkevåg, A., Seland, Ø., Heinze, C., and Ilyina, T.: Amplification of global warming through $\mathrm{pH}$ dependence of DMS production simulated with a fully coupled Earth system model, Biogeosciences, 14, 3633-3648, https://doi.org/10.5194/bg-14-3633-2017, 2017.

Shaw, G. E.: Bio-controlled thermostasis involving the sulfur cycle, Climatic Change, 5, 297-303, 1983.

Simó, R.: Production of atmospheric sulfur by oceanic plankton: biogeochemical, ecological and evolutionary links, Trends Ecol. Evol., 16, 287-294, https://doi.org/10.1016/S01695347(01)02152-8, 2001.

Singh, D., Bollasina, M., Ting, M., and Diffenbaugh, N. S.: Disentangling the influence of local and remote anthropogenic aerosols on South Asian monsoon daily rainfall characteristics, Clim. Dynam., 52, 6301-6320, https://doi.org/10.1007/s00382-018-45129, 2018.

Six, K. D., Kloster, S., Ilyina, T., Archer, S. D., Zhang, K., and Maier-Reimer, E.: Global warming amplified by reduced sulphur fluxes as a result of ocean acidification, Nat. Clim. Change, 3, 975-978, https://doi.org/10.1038/NCLIMATE1981, 2013. 
Skirving, W. J., Enríquez, S., Hedley, J., Dove, S., Eakin, C., Mason, R., De La Cour, J., Liu, G., Hoegh-Guldberg, O., and Strong, A.: Remote sensing of coral bleaching using temperature and light: progress towards an operational algorithm, Remote Sens., 10, 18, https://doi.org/10.3390/rs10010018, 2018.

Skirving, W. J., Heron, S. F., Marsh, B. L., Liu, G., De La Cour, J. L., Geiger, E. F., and Eakin, C. M.: The relentless march of mass coral bleaching: a global perspective of changing heat stress, Coral Reefs, 38, 547-557, https://doi.org/10.1007/s00338-01901799-4, 2019.

Spalding, M., Ravilious, C., and Green, E. P.: World atlas of coral reefs, University of California Press, California, USA, 2001.

Spalding, M., Burke, L., Wood, S. A., Ashpole, J., Hutchison, J., and zu Ermgassen, P.: Mapping the global value and distribution of coral reef tourism, Mar. Policy, 82, 104-113, https://doi.org/10.1016/j.marpol.2017.05.014, 2017.

Spracklen, D. and Rap, A.: Natural aerosol-climate feedbacks suppressed by anthropogenic aerosol, Geophys. Res. Lett., 40, 5316-5319, https://doi.org/10.1002/2013GL057966, 2013.

Stefels, J.: Physiological aspects of the production and conversion of DMSP in marine algae and higher plants, J. Sea Res., 43, 183197, https://doi.org/10.1016/S1385-1101(00)00030-7, 2000.

Stein, A., Draxler, R., Rolph, G., Stunder, B., Cohen, M., and Ngan, F.: NOAA's HYSPLIT atmospheric transport and disperion modelling system, B. Am. Meteorol. Soc., 96, 2059-2077, https://doi.org/10.1175/BAMS-D-14-00110.1, 2015.

Steiner, Z., Turchyn, A. V., Harpaz, E., and Silverman, J.: Water chemistry reveals a significant decline in coral calcification rates in the southern Red Sea, Nat. Commun., 9, 3615, https://doi.org/10.1038/s41467-018-06030-6, 2018.

Steinke, M., Brading, P., Kerrison, P., Warner, M. E., and Suggett, D. J.: Concentrations of dimethylsulfoniopropionate and dimethyl sulfide are strain-specific in symbiotic Dinoflagellates (Symbiodinium sp., Dinophyceae), J. Phycol., 47, 775-783, https://doi.org/10.1111/j.1529-8817.2011.01011.x, 2011.

Sun, J., Todd, J. D., Thrash, J. C., Qian, Y., Qian, M. C., Temperton, B., Guo, J., Fowler, E. K., Aldrich, J. T., and Nicora, C. D.: The abundant marine bacterium Pelagibacter simultaneously catabolizes dimethylsulfoniopropionate to the gases dimethyl sulfide and methanethiol, Nat. Microbiol., 1, 16065, https://doi.org/10.1038/NMICROBIOL.2016.65, 2016.

Sunda, W., Kieber, D., Kiene, R., and Huntsman, S.: An antioxidant function for DMSP and DMS in marine algae, Nature, 418, $317-$ $320,2002$.

Surratt, J. D., Kroll, J. H., Kleindienst, T. E., Edney, E. O., Claeys, M., Sorooshian, A., Ng, N. L., Offenberg, J. H., Lewandowski, M., and Jaoui, M.: Evidence for organosulfates in secondary organic aerosol, Environ. Sci. Technol., 41, 517-527, https://doi.org/10.1021/es062081q, 2007.

Swan, H. B., Crough, R. W., Vaattovaara, P., Jones, G. B., Deschaseaux, E. S., Eyre, B. D., Miljevic, B., and Ristovski, Z. D.: Dimethyl sulfide and other biogenic volatile organic compound emissions from branching coral and reef seawater: potential sources of secondary aerosol over the Great Barrier Reef, J. Atmos. Chem., 73, 303-328, https://doi.org/10.1007/s10874016-9327-7, 2016.

Swan, H. B., Jones, G. B., Deschaseaux, E. S. M., and Eyre, B. D.: Coral reef origins of atmospheric dimethylsulfide at Heron
Island, southern Great Barrier Reef, Australia, Biogeosciences, 14, 229-239, https://doi.org/10.5194/bg-14-229-2017, 2017a.

Swan, H. B., Deschaseaux, E. S. M., Jones, G. B., and Eyre, B. D.: The relative abundance of dimethylsulfoniopropionate (DMSP) among other zwitterions in branching coral at Heron Island, southern Great Barrier Reef, Analyt. Bioanalyt. Chem., 409, 4409-4423, https://doi.org/10.1007/s00216-017-0385-8, 2017b.

Takahashi, Y., Okazaki, Y., Sato, M., Miyahara, H., Sakanoi, K., Hong, P. K., and Hoshino, N.: 27-day variation in cloud amount in the Western Pacific warm pool region and relationship to the solar cycle, Atmos. Chem. Phys., 10, 1577-1584, https://doi.org/10.5194/acp-10-1577-2010, 2010.

Thume, K., Gebser, B., Chen, L., Meyer, N., Kieber, D. J., and Pohnert, G.: The metabolite dimethylsulfoxonium propionate extends the marine organosulfur cycle, Nature, 563, 412-415, https://doi.org/10.1038/s41586-018-0675-0, 2018.

Todd, J. D., Rogers, R., Li, Y. G., Wexler, M., Bond, P. L., Sun, L., Curson, A. R., Malin, G., Steinke, M., and Johnston, A. W.: Structural and regulatory genes required to make the gas dimethyl sulphide in bacteria, Science, 315, 666-669, https://doi.org/10.1126/science.1134562, 2007.

Tresguerres, M., Barott, K. L., Barron, M. E., Deheyn, D. D., Kline, D. I., and Linsmayer, L. B.: Cell biology of reef-building corals: ion transport, acid/base regulation, and energy metabolism, in: Acid-Base Balance and Nitrogen Excretion in Invertebrates, Springer, Cham, 193-218, https://doi.org/10.1007/978-3-31939617-0_7, 2017.

Vallina, S. M., Simó, R., Gassó, S., de Boyer-Montégut, C., del Río, E., Jurado, E., and Dachs, J.: Analysis of a potential "solar radiation dose-dimethylsulfide-cloud condensation nuclei" link from globally mapped seasonal correlations, Global Biogeochem. Cy., 21, 506-508, https://doi.org/10.1029/2006GB002787, 2007.

Van Alstyne, K. L. and Puglisi, M. P.: DMSP in marine macroalgae and macroinvertebrates: Distribution, function, and ecological impacts, Aquat. Sci., 69, 394-402, https://doi.org/10.1007/s00027-007-0888-z, 2007.

Van Alstyne, K. L., Dominique, V., and Muller-Parker, G.: Is dimethylsulfoniopropionate (DMSP) produced by the symbionts or the host in an anemone-zooxanthella symbiosis?, Coral Reefs, 28, 167-176, https://doi.org/10.1007/s00338-008-0443-y, 2009.

Van Oppen, M. J., Oliver, J. K., Putnam, H. M., and Gates, R. D.: Building coral reef resilience through assisted evolution, P. Natl. Acad. Sci. USA, 112, 2307-2313, https://doi.org/10.1073/pnas.1422301112, 2015.

Veres, P. R., Neuman, J. A., Bertram, T. H., Assaf, E., Wolfe, G. M., Williamson, C. J., Weinzierl, B., Tilmes, S., Thompson, C. R., and Thames, A. B.: Global airborne sampling reveals a previously unobserved dimethyl sulfide oxidation mechanism in the marine atmosphere, P. Natl. Acad. Sci. USA, 117, 4505-4510, https://doi.org/10.1073/pnas.1919344117, 2020.

von Glasow, R. and Crutzen, P. J.: Model study of multiphase DMS oxidation with a focus on halogens, Atmos. Chem. Phys., 4, 589608, https://doi.org/10.5194/acp-4-589-2004, 2004.

Ward, S., Harrison, P., and Hoegh-Guldberg, O.: Coral bleaching reduces reproduction of scleractinian corals and increases susceptibility to future stress, in: Proceedings of the Ninth International Coral Reef Symposium, 23-27 October 2000, Bali, 1123-1128, 2002 . 
Webb, A., van Leeuwe, M., den Os, D., Meredith, M., Venables, H., and Stefels, J.: Extreme spikes in DMS flux double estimates of biogenic sulfur export from the Antarctic coastal zone to the atmosphere, Scient. Rep., 9, 2233, https://doi.org/10.1038/s41598019-38714-4, 2019.

Wilkinson, C. R., Lindén, O., Cesar, H. S., Hodgson, G., Rubens, J., and Strong, A. E.: Ecological and socioeconomic impacts of 1998 coral mortality in the Indian Ocean: An ENSO impact and a warning of future change?, Ambio, 28, 188-196, 1999.

Woodhouse, M., Carslaw, K., Mann, G., Vallina, S., Vogt, M., Halloran, P., and Boucher, O.: Low sensitivity of cloud condensation nuclei to changes in the sea-air flux of dimethyl-sulphide, Atmos. Chem. Phys., 10, 7545-7559, https://doi.org/10.5194/acp10-7545-2010, 2010.

Woodhouse, M. T., Mann, G. W., Carslaw, K. S., and Boucher, O.: Sensitivity of cloud condensation nuclei to regional changes in dimethyl-sulphide emissions, Atmos. Chem. Phys., 13, 27232733, https://doi.org/10.5194/acp-13-2723-2013, 2013.

Wooldridge, S. A. and Brodie, J. E.: Environmental triggers for primary outbreaks of crown-of-thorns starfish on the Great Barrier Reef, Australia, Mar. Pollut. Bull., 101, 805-815, https://doi.org/10.1016/j.marpolbul.2015.08.049, 2015.
Yakovleva, I. M., Baird, A. H., Yamamoto, H. H., Bhagooli, R., Nonaka, M., and Hidaka, M.: Algal symbionts increase oxidative damage and death in coral larvae at high temperatures, Mar. Ecol. Prog. Ser., 378, 105-112, https://doi.org/10.3354/meps07857, 2009.

Yang, M., Blomquist, B., Fairall, C., Archer, S., and Huebert, B.: Air-sea exchange of dimethylsulfide in the Southern Ocean: Measurements from SO GasEx compared to temperate and tropical regions, J. Geophys. Res.-Oceans, 116, C00F05, https://doi.org/10.1029/2010JC006526, 2011.

Zavarsky, A., Booge, D., Fiehn, A., Krüger, K., Atlas, E., and Marandino, C.: The influence of air-sea fluxes on atmospheric aerosols during the summer monsoon over the tropical Indian Ocean, Geophys. Res. Lett., 45, 418-426, https://doi.org/10.1002/2017GL076410, 2018.

Zeebe, R. E. and Tyrrell, T.: History of carbonate ion concentration over the last 100 million years II: Revised calculations and new data, Geochim. Cosmochim. Ac., 68, 3521-3530, https://doi.org/10.1016/j.gca.2019.02.041, 2019.

Zhang, Z., Jones, A., and Crabbe, M. J. C.: Impacts of stratospheric aerosol geoengineering strategy on Caribbean coral reefs, Int. J. Clim. Change Strat. Manage., 10, 523-532, https://doi.org/10.1108/IJCCSM-05-2017-0104, 2017. 